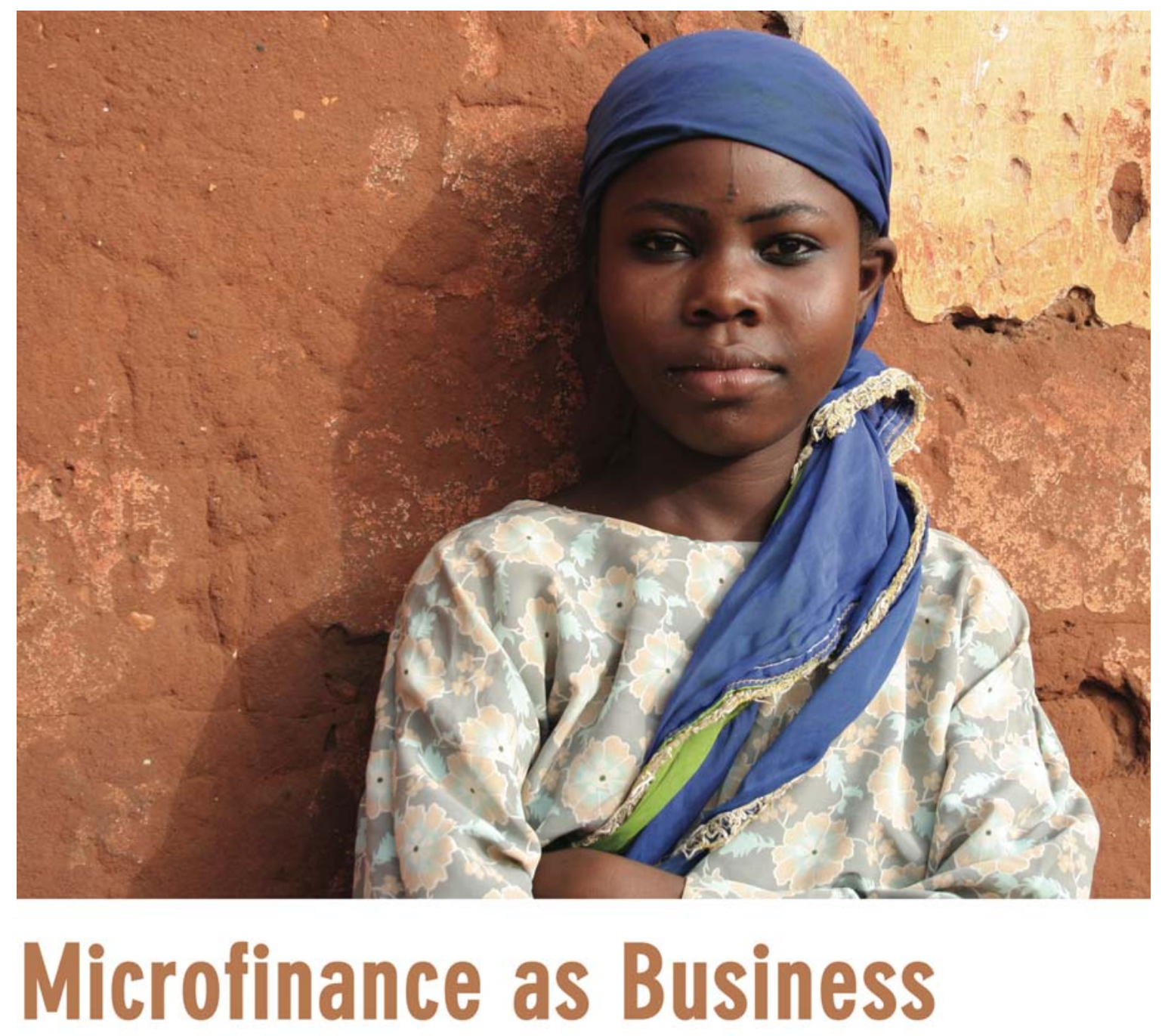

David Roodman, Research Fellow
Uzma Qureshi, Consultant 



\title{
Microfinance as Business
}

\author{
David Roodman, Research Fellow \\ Uzma Qureshi, Consultant
}

November 2006

The authors thank ABN AMRO for financial support, Thierry van Bastelaer, Dean Karlan, and Jonathan Lewis for thoughtful reviews, and all the interviewees (see Appendix) for their generosity with their time. Above all, the authors thank Khalid Sheikh and Suellen Lazarus for conceiving of the project and for inspiration, deadlines, and excellent feedback. The views expressed are the responsibility of the authors only. 



\section{Contents}

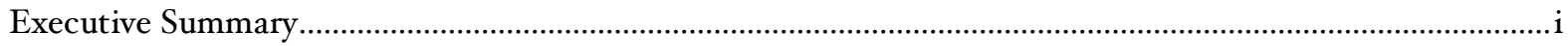

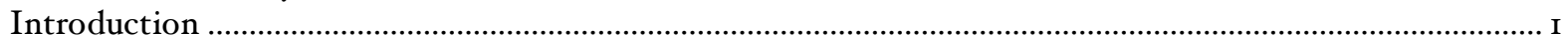

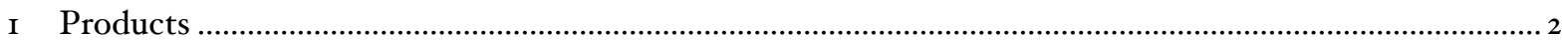

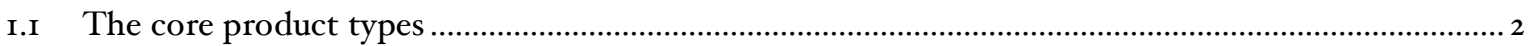

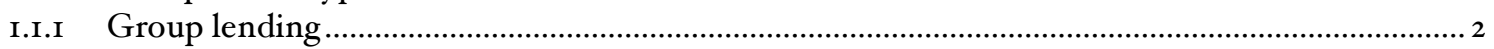

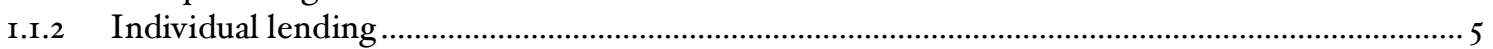

I.I.3 A conceptual framework for microcredit methodologies..................................................................6

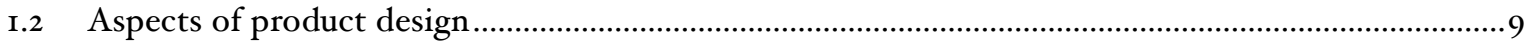

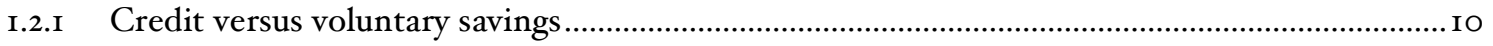

I.2.2 Dynamic incentives...............................................................................................................

I.2.3 Lending to women .............................................................................................................. I4

I.2.4 Frequent transactions and short loan terms........................................................................... I6

I.2.5 Matching rates to costs ............................................................................................................ I6

I.2.6 Limited product offerings and streamlined procedures ............................................................. I8

I.2.7 Forced savings......................................................................................................................... I9

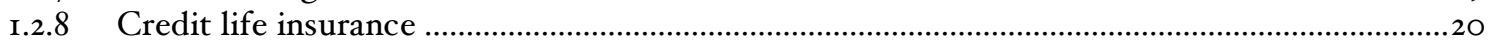

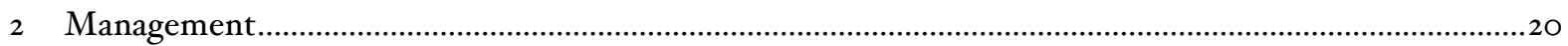

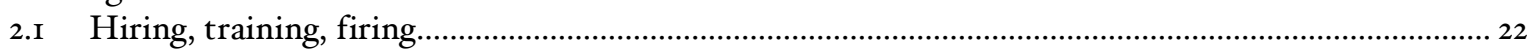

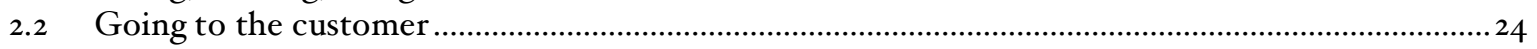

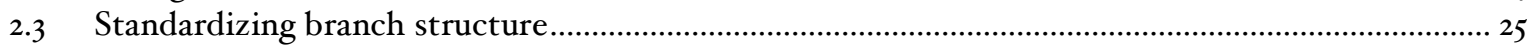

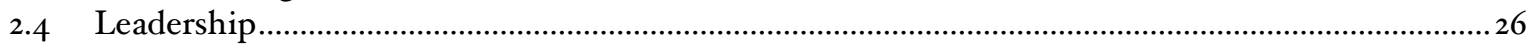

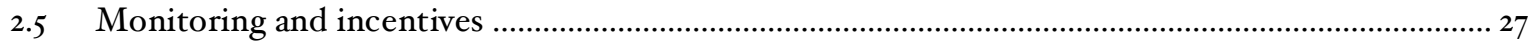

2.6 Organizational capacity for learning ………............................................................................ 28

3 Enabling environment.......................................................................................................................

3.I Positive feedback loops: microfinance begets microfinance ……........................................................ I

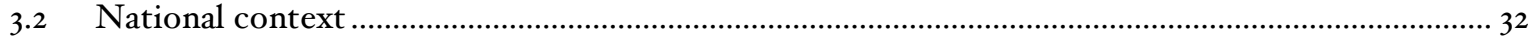

3.2.I Wage rates ........................................................................................................................... 32

3.2.2 Competition from the non-MFI private sector ..............................................................................3

3.2.3 Economic and political competition from subsidized government credit.................................34

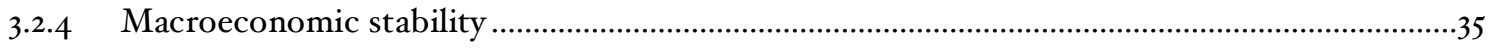

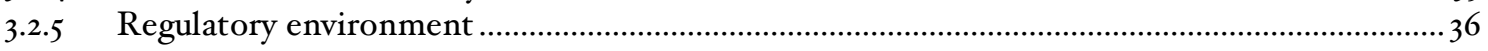

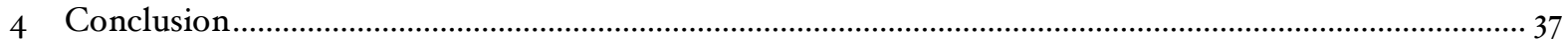

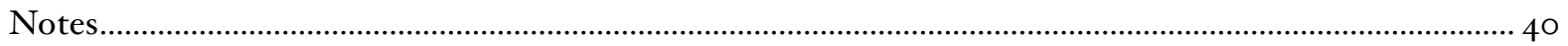

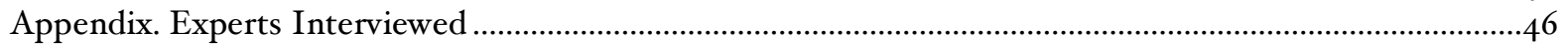

\section{Tables and figures}

Table I. Characteristics of MFIs reporting to the Microbanking Bulletin survey, 2004 (medians) ..................................

Table 2. Borrowers per loan officer by lender type (median), MicroBanking Bulletin survey, 2004 …............................... 8

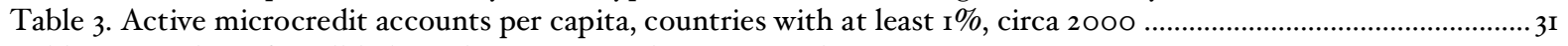

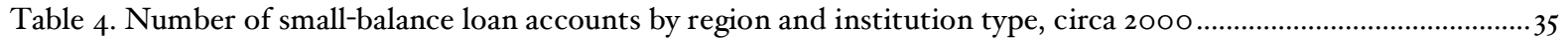

Figure I. Expenses as a share of outstanding loans by lender type (median), MicroBanking Bulletin survey, 2004 ……..... 8

Figure 2. Expenses per loan by lender type (median), MicroBanking Bulletin survey, 2004 ………………….................. 8

Figure 3. Loan sizes in dollars and fraction of GNI/capita by lender type (median), MicroBanking Bulletin survey,

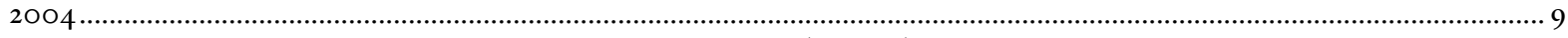

Figure 4. Share of borrowers who are women by lender type (median), MicroBanking Bulletin survey, 2004 ……............ 4

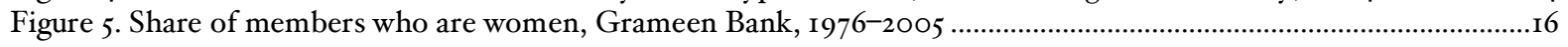

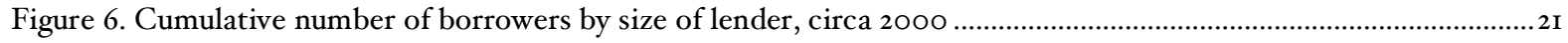






\section{Executive Summary}

IN THIS PAPER, we analyze microfinance institutions (MFIs) as businesses, asking how some MFIs succeed in reducing and covering costs, earning returns, attracting capital, and scaling up. We are interested in MFIs that are financially self-sufficient (covering the cost of daily operations as well as the cost of capital at a commercial rate) or merely operationally selfsufficient (not covering capital costs) or only, say, 90\% operationally self-sufficient. All such MFIs strive for efficiency and are in many respects businesslike.

Our interest in commercial success does not mean that we believe that it is the raison d'être of microfinance. The ultimate impact on borrowers and communities is what matters for MFI leaders and staffers, as well as for nearly all their investors, by which we mean those who put money in, public or private, through grants, loans, or equity. We focus here on commercial success because viewing MFIs as practical solutions to challenging business problems is a good place to start in understanding why most microfinance operates in the ways it does, what impact it is having, and how it can realistically be expected to enhance its impact.

Based on a survey of existing literature and interviews with key microfinance playersacademics, MFI executives, industry analysts in MFI rating agencies, and investors (see Appendix) - we strive to uncover the major innovations in product design and management techniques that have allowed MFIs to offer financial products to a clientele that had been deemed too poor, too risky, and too costly for banks to serve. We also survey contextual factors such as economic and political conditions that hinder or facilitate microfinance.

Although the capacity of the poor to borrow and save is counterintuitive for some people, their need to do so is actually greater than for better-off people. Precisely because their incomes are tight, and often volatile, financial services that help them fill in mismatches between income and consumption needs can be a matter of survival. And though seemingly opposite, lending and savings are similar in helping households manage these mismatches. They can both help people accumulating capital for investment too.

Thus in commercial terms, there is a market for microfinance. But to serve that market on a sustainable basis, and grow, MFIs must push costs below revenues, or at least bring them close enough that the need for subsidy does not throttle growth. That requires solving some tough business problems. Key microfinance business challenges include:

- Building volume.

- Keeping loan repayment rates high.

- Retaining customers.

- Minimizing scope for fraud in branches.

Since the I970s, MFI innovators have invented or discovered clever solutions to the microfinance business problem. Some have built huge organizations that serve millions of clients and have demonstrated an impressive capacity for change-all that, to boot, in places with weak stocks of infrastructure and human capital. The individual innovations in product design and management have spread both through a Darwinian process of selection- the techniques that worked are 
found in the large MFIs because they help them become large - and through cultural diffusion, as other MFIs imitated the most successful ones. At barely 30 years old, microfinance is hardly as refined as the human eye after millions of years of evolution: the tinkering goes on.

In surveying the diversity of microfinance today, the paper looks at three kinds of success factors: design of products, such as group lending, individual lending, and savings; management techniques that build organizations to deliver these services on a large scale; and environmental factors that make some countries hospitable to microfinance and others not.

\section{Products}

THE TERM "MICROFINANCE" includes the provision of a wide range of financial services to the poor: savings, insurance, money transfers, and credit. The microfinance movement to date, however, has generally favored microcredit, so much of our analysis is devoted to that.

The dominant types of microcredit can be seen as arrayed along a spectrum. At one end, loans are smaller, relatively more costly to provide, and are made practical by giving the job of client selection and monitoring to borrowers themselves. At the other end, loans are larger, cheaper to administer (relative to loan size), and less burdensome for the client. Moving to specifics, we discuss these features of product design:

- Emphasis on credit over voluntary savings

- Progressive lending - offering bigger loans to those who first repay small ones

- (Group) lending to women

- Frequent transactions and short loan terms

- Matching interest rates to costs

- Limited product offerings and streamlined procedures

- Forced savings

- Credit life insurance

We conclude that much about how microfinance operates today can be explained by the commercial imperative to control costs while delivering services customers will buy.

\section{Management}

THE PRODUCT CHOICES outlined above are all fairly common; yet few MFIs can be called commercial success stories. In data from the years around 2000, $3 \%$ of MFIs, 73 of them, held $80 \%$ of microloan accounts worldwide (a total of 40 million). This lopsided distribution shows that commercial success is about more than product design. It also requires effective management. The report groups management techniques under these headings:

- Hiring, training, and firing with an eye toward inculcating a social mission and commitment to excellence

- Going to the customer

- Standardizing branch structure

- Leadership 
- Monitoring and incentives

- Organizational capacity for learning

The picture that emerges is of the successful MFI as a decentralized organization. Retail units go to the customer and are the locus of production. They are where relationships with clients are made and maintained, where services are provided, where much learning should take place about the effectiveness of current approaches, where growth can occur through splitting of units. Excessive intervention in branch activities would slow and demoralize workers. Managementthe center-picks and trains the right people; designs the products and the structure of local offices; gives them substantial operational autonomy for the sake of efficiency and morale; monitors their performance through strong management information systems (MIS); guides them by inculcating a culture of excellence and service and offering pay incentives; and seeks to learn continually from experience in the field.

\section{Enabling Environment}

ONLY TEN COUNTRIES had more than 3 microfinance accounts per IOo people circa 2000. Surely microfinance leaders such as Indonesia, Bolivia, and Bangladesh do not hold monopolies on microfinance know-how, talent, and initiative. Environmental factors such as government policies and economic circumstances must also be at play. Indeed, it is hard to escape the conclusion that environmental factors explain more of the variation across countries than anything else. Among the factors:

- Wage rates for loan officers relative to income of clients

- Competition from the non-MFI private sector

- Competition from subsidized government credit

- Macroeconomic stability

- The regulatory environment

To a substantial extent, microfinance does appear to be a case in which the "field of dreams" approach - if you build it, they will come-works. If domestic governments set the stage and do not meddle, MFI entrepreneurs and investors will come. Economic circumstances, such as competition from consumer lenders in Brazil and high wages for skilled labor in Africa relative to the incomes of the poor, do narrow the scope for microfinance.

\section{Conclusions}

THAT MICROFINANCE TODAY is the outcome of an evolutionary process means that nontraditional entrants, such as commercial banks, need to exercise care in adopting established models. Models that were optimal for non-banks may not be optimal for banks. In particular, to the extent that the traditional emphasis on credit is an adaptive response to the difficulty that NGOs face in taking savings, rather than the demonstrably superior way to relieve the capital constraints of the poor and smooth their spending, banks entering microfinance should seriously 
explore taking deposits. Savings can generate income, and do not impose the same risks as credit. Notably, the Bank Rakyat Indonesia (BRI) - as a century-old bank, an anomaly within the microfinance world - had 32.3 million deposit accounts to 3 million loan accounts at end-2005.

This study also casts an interesting sidelight on the contribution of microfinance to development. Essentially all investors in microfinance are looking at a "double bottom line"commercial success and social gain. The mere existence of BancoSol, Grameen, BRI, and other commercially successful MFIs is a kind of development in itself since they permanently enrich the institutional fabric of their countries. But many microfinance investors are searching for another kind of success: direct benefits for clients and their families. Yet rigorously derived evidence on how much microcredit helps people is surprisingly thin. Despite the growing clientele and high repayment rates, it is not as clear as we would like where and when microcredit improves lives.

Microcredit, like all credit, helps some people-one hopes, the majority of clients. And like all credit, especially when pushed hard by suppliers, microcredit must hurt some clients too. This complexity is no more a reason to attack microcredit per se than is personal bankruptcy in rich countries a cause for banning credit cards or home mortgages. But in combination with the observation that commercial imperatives can explain so much about how microfinance is done, is a cause for reflection. For example, the historical emphasis among MFIs on credit rather than savings appears to have arisen for practical business reasons rather than because it has been shown that credit helps clients more. Microfinance investors should therefore work to understand how MFIs succeed on both bottom lines-as businesses and as agents of development. 


\section{Introduction}

TYPICAL ACCOUNTS OF microfinance history tell us that in the I970s an imaginative experimenter - most often it is Muhammad Yunus in Bangladesh, but sometimes it is workers for Acción International in Brazil or Opportunity International in Colombia-discovered that

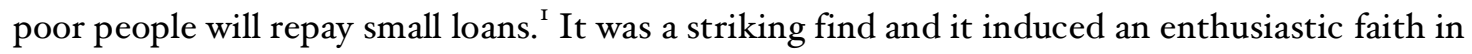
the power of microcredit to lift the poor out of poverty. Almost three decades later, the microfinance movement boasts numerous success stories-small, grass root organizations that have grown phenomenally in size while maintaining high rates of profitability. The Grameen Bank, for example, today boasts a Nobel Prize, I,700 branches, r6, o०o employees, and 6 million customers, $96 \%$ of them women. ${ }^{2}$ In Bolivia, BancoSol, with 62,00o borrowers, is a commercial offshoot of the non-profit PRODEM, which itself is descended from the world's first "solidarity group" lending experiments, by Acción.

Since the I970s, several major methodologies have developed for delivering credit and other financial services to poor customers. The dollar sums transacted in these methodologies range from under \$50 to over \$I,O०o, and they help people do everything from buy food in a pinch to acquire sewing equipment for cottage manufacturing. What they have in common is a strong role for foreigners, who continue to both advise and invest - where by "invest" we mean provide grants, loans, or equity participation. On a global basis, microfinance institutions (MFIs) in fact provide a minority of financial services to the poor, mainly because of huge government programs in China, India, and Viet Nam. ${ }^{3}$ But because of the opportunities they offer people in rich countries to invest and advise, and because of their rapid growth, MFIs are our focus.

Enthusiasm about the power of microfinance to alleviate poverty has colored most accounts of the microfinance story. In this paper, however, we get away from the rhetoric around microfinance by focusing on the business choices of commercially successful microfinance institutions. This is not to imply that commercial success is all that matters for microfinance. The ultimate impact on borrowers and communities is what matters most, not least to the public and private donors and investors that support MFIs. Nor do we mean to engage in the debate about whether commercial success should be a priority. One can argue that it should be, for the sake of serving as many people as possible. But, as a counterexample, in Bolivia, ProMujer and Crecer bundle educational and health services with credit and believe that dropping the services for the sake of cost-cutting would undermine their mission to aid the poorest. ${ }^{4}$

Still, even ProMujer and Crecer have converged to a relatively commercial mode of operation. Thus, we believe that viewing MFIs as practical solutions to challenging business problems is a good place to start in understanding why they operate in the ways they do, and how they can realistically be expected to improve. As Pankaj Jain and Mick Moore write, "To properly appreciate the great achievements of the microcredit movement, one has to be more skeptical of its self-image than is normally considered polite or respectful."

Based on a survey of existing literature and interviews with key players in the microfinance sector-academics, MFI executives, industry analysts in MFI rating agencies and investors-we strive to uncover the major microfinance innovations that have allowed MFIs to sustainably offer financial products to a clientele that had been deemed too poor, too risky and too costly to be 
served by banks in the past. In particular, we review the products that microfinance innovators have developed since the early I970s to solve the business problem of delivering financial services, especially credit, at manageable cost to poor people. We go on to examine management techniques, from training to pay incentives, that they use to build and run effective organizations to deliver these services on a large scale. Finally, we investigate one of the tougher puzzles in microfinance, the environmental factors that appear to make some countries good homes for microfinance and others inhospitable. Why does Bolivia have more microfinance than Peru, Cambodia more than Vietnam, and Benin more than Nigeria?

Our purpose is to provide a conceptual survey of this vast topic, which we do with great humility about the actual diversity of microfinance around the world. The big picture that emerges is of an interaction between human ingenuity and evolutionary dynamics. Microfinance leaders have found a suite of techniques in product design and management that solve the fundamental microfinance problems of controlling costs, building volume, keeping repayment high, and preventing internal fraud, all while operating in a poor country. Most of these techniques they have consciously designed. Others they have stumbled upon; but because they work, their organizations moved to the forefront of the microfinance movement, through a process of "natural" selection. But so hostile is the environment in many countries that microfinance has so far flourished only in a few places.

\section{Products}

THE TERM "MICROFINANCE" includes the provision of a wide range of financial services to the poor: credit, savings, insurance, and money transfers. The microfinance movement to date, however, has heavily favored microcredit, so much of our analysis focuses on innovations in credit delivery. Throughout, our interest is in how products are designed for financial sustainability, which is when MFIs cover operational costs, costs of capital, and loan losses.

\subsection{The core product types}

Group lending products are the ones most commonly associated in the public's mind with the microfinance revolution. They come in two major types: group and individual lending.

\subsubsection{Group lending}

In classic solidarity group lending, which both Acción International and the Grameen Bank developed, borrowers are asked to form groups of three to seven members, most commonly five. Borrowers in a group are jointly and severally liable for all loans taken out, meaning they are each liable for the others' loans and any one of them can be held fully responsible for an outstanding loan. Typically the pattern of disbursements and repayments is regimented. In the classic Grameen model, payments begin immediately after disbursement, are due weekly, and are constant over the life of the loan. Entry into the regimen is staggered within a group: first two borrowers take their loans and begin to repay, then two more, then the fifth. When a loan is repaid, the borrower becomes immediately eligible for a larger one as long as all group members 
are in good standing and approve the individual loan requests. In the classic model, eight solidarity groups are federated into a larger group called the "center," which gathers each week with a loan officer to perform all financial transactions.

The other major type of group lending is village banking, and was developed in 1984 in Bolivia by John Hatch, who went on to found FINCA International. Village banks bring together 15 to 30 people, give them a single loan, then delegate authority to them for on-lending to individual members. This delegation distinguishes village banking from most other forms of microfinance. Members elect the office holders of the village bank, who assume responsibility for conducting its affairs. Usually, loan sizes are allowed to differ among individual members. But all loans carry the same repayment and interest rate terms, and borrowers are generally offered a loan ladder, a sequence of 3 to 5 loan cycles with a maximum loan size specified for each cycle. For example, Compartamos, a profitable and fast-growing microfinance institution in Mexico, offers a threestep loan ladder for its village banking product, with the first loan at most \$150 and the third at most \$1400. ${ }^{6}$ Village bank members act as co-guarantors and help decide how much each person borrows. Because the groups are larger than solidarity groups, village banking more frequently faces the problems that arise when there are large spreads in loan size within the jointly liable group, which can expose the poorest members to inordinate risk. To protect them, most village banking MFIs try to keep the maximum-to-minimum loan ratio below ro. ${ }^{7}$

Though distinct, the two dominant forms of group lending have much in common. Both have regular, compulsory public meetings, typically weekly or biweekly, where loans are repaid and disbursed and savings collected. In both kinds of lending, it is not uncommon for the attending loan officer to refuse to end the meeting until all scheduled loan repayments are made- by someone.

Economists have taken note of one traditional feature of both forms of group lending, joint liability. The theoretical literature has viewed joint liability as a major technological innovation that reduces problems arising from "informational asymmetries" between lender and borrower. ${ }^{8}$ In both village banking and solidarity lending, groups self-select. Given members' superior knowledge of the character and economic circumstances of friends and neighbors, they can do better than the lender at screening out risky borrowers prior to the loan decision and monitoring loan use after.

Though economists initially saw joint liability as the key innovation that kept repayment rates high, there were puzzling questions. If members knew that others in the group would make up their repayments if they defaulted, why don't they free ride on others and default more often? This highlights the peer pressure exercised in closed community groups, and the importance of reputation, honor, and shame. Honor is both a matter of public reputation and a private concept: the popularity of death insurance offered by some MFIs demonstrates that people in some cultures think they have failed their worldly and religious duties if they leave debt for their heirs.

Case-studies have revealed that, MFIs that require joint liability usually do not enforce it. Instead, a common practice is to encourage other members of the solidarity group center - the larger or "secondary group" that is not party to the formal joint-liability clause-to make up the default amount. Jain and Moore write: 
Secondary groups play a more specific role in facilitating loan repayment in the initial phase of some programs. When a member can neither meet loan repayment schedules nor source other money for this purpose, field workers encourage her to take a short-term, interest free and typically informal (but publicly known) loan from other member(s) of the secondary group (not especially the primary group) and agree to repay installments in parallel with the program loan....In the longer established [MFIs] and secondary groups, willingness to provide such temporary loans has declined over time. In such cases...potential defaulters are expected to find alternate loan sources outside of the secondary group, and prior to the weekly group meeting to avoid disrupting it.?

This quote illustrates the multiple sources of peer pressure on the defaulter. First, the defaulter is identified in front of the entire village center. Second, she is put in a position where she must publicly ask for help. Third, she becomes responsible for the community center meeting being prolonged and any unpleasantness that might ensue. Lengthy meetings have been cited as an important reason clients drop out from group lending programs, so when a loan officer does not allow the meeting to end unless all defaults have been covered, it must add to the social pressure. $^{\text {IO }}$

The public nature of group lending and the resulting play of honor and shame thus appear to be more essential to timely repayment than formal joint liability. Consider the rapid growth of the Association for Social Advancement (ASA) in Bangladesh, which does group lending with individual liability. ASA's success is likely a reason that Grameen Bank dropped joint liability as part of its reforms around 200I, dubbed "Grameen II," but retained the rest of the credit

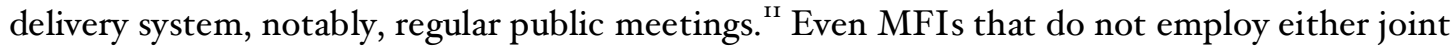
liability or regular group meetings for transaction purposes tap into this sensitivity to reputation for delinquency control: XacBank in Mongolia posts names of clients and their installment repayment reports on the walls of its branches. ${ }^{12}$ Peer pressure, it seems, is a broader concept than first assumed within a group liability context. It is not simply the pressure exerted by fellow group members who are afraid of losing access to future loans or having to cover loan delinquencies, it is pressure arising from public transactions in communities where individuals worry about reputations. And the discovery is not really new to microcredit; money lenders too have used public honor to motivate repayments. When interviewed, a woman street vendor who was a client of a group of moneylenders called "the Bombays" in the Philippines "noted that the Bombays always picked the busiest hour of the day to collect so that there would always be witnesses to her embarrassment." ${ }^{13}$

Experimental research is confirming the relative unimportance of formal joint liability. In an experiment run with the Green Bank of Caraga in the Philippines, Xavier Giné and Dean Karlan found that after borrowers in randomly chosen, ongoing solidarity groups were notified that joint liability had been dropped, repayment rates and other indicators of portfolio health showed no change in the following year-except that centers without joint liability attracted more new clients. ${ }^{\text {I4 }}$ It remains to be seen whether joint liability is similarly unimportant in the earlier, group formation stage, where self-selection appears to screen out bad risks (adverse selection). The experiments reported so far have been done only by switching existing borrowers, who already went through a joint-liability-bound group building process. 
In sum, it is becoming clear that group lending works in part by substituting reputation for conventional collateral-in other words, collateralizing reputation. (Section I.2.2 describes "forced savings" which also function as collateral for group lenders.) Group lending is public banking for the poor, in contrast with private banking for the rich. The growth of ASA and the Green Bank experiment suggest the obvious: the poor like joint liability no more than the rich and accept it only when they have no better option.

A relative of village banking is the self-help group (SHG) system that dominates microfinance in India. The system evolved from the efforts of NGOs to organize the rural poor, especially women, into groups for purposes of social and economic empowerment through group savings, education, and microenterprise support. NGOs train the group in saving, lending, and accounting, then link the group with a bank where the it can deposit its accumulated savings into a collective account. The bank then grants a block loan to the group, typically four times as large as the savings balance, for which members are jointly and severally liable. ${ }^{15}$ The group decides how, and on what terms, to distribute the loan to individual members. Self-help microfinance took off when the Indian government decided to support it through the National Bank for Agricultural Development (NABARD), which provides subsidized refinancing to banks for their lending to SHGs. Partly because several steps separate clients from NABARD, there are no national statistics on how many Indians participate in SHGs. In fiscal year 2004-05, 798,000 SHGs received bank loans, 539 , o o o for the first time, bringing the cumulative number of SHGs receiving loans to I.618 million. ${ }^{\mathrm{I}}{ }^{6}$ At a typical 17 women per group, that suggests that up to 27 million women have joined SHGs. ${ }^{17}$ However, many of the SHGs may have gone defunct, and their members may have joined new groups, so this figure could be high by a factor of two or three.

The success to date of SHGs in India is attributable to a combination of special factors: a proliferation of grass-root NGOs dedicated to the economic and social uplift of rural communities; a vast network of public-sector rural banks; the popular acceptance, even expectation, of state-subsidized poverty alleviation programs; and a committed champion in the NABARD. However, some of these same factors pose potential challenges to a further scaling up of the Bank Linkage Program, which still reaches only a small fraction of Indians. The central problem is the misalignment of incentives. Since the job of the partner NGOs is to form groups, not run them on an ongoing basis, they do not face the same financial incentives as MFIs to maintain portfolio quality. The professionalism and commitment to mission of the established NGOs that historically formed SHGs may have compensated for the perverse incentives. But as NABARD pushes for growth, the risk increases that new organizations will arise purely to form SHGs, and will not behave so well. In the worst case, they collude with borrowers against a lender for short-term gain. The misaligned incentives are why the private ICICI Bank, which has lent to $\mathrm{I2}, \mathrm{OOO}$ SHGs, is now moving to MFIs as a channel as it scales up in microfinance. ${ }^{\mathrm{I}}$

\subsubsection{Individual lending}

Individual lending is the other major type of microcredit methodology. As its name makes obvious, it is built around more conventional lending relationships with individual clients. But in contrast with conventional lending, individual microlending of course offers smaller loans, on the 
order of \$I,OOO, and relies less on traditional sources of security, such as marketable collateral, credit bureaus, and formal legal recourse. It relies more on informal assessments of character and business operations. Group lending puts the burden of this assessment on the group through the group self-selection mechanism; individual lending depends on the loan officer to perform this screening. In dense urban areas, notably in Latin America, where social bonds may not be strong enough to support group lending, individual lending must tap into the borrower's social assets by forming a character sketch from interviews with friends, neighbors, and business associates. Gabriel Solorzano, President of Nicaragua's FINDESA, explains that his finance company extends not "asset-based credit" (ABC) but "integrity-based credit" (IBC). ${ }^{19}$ Claus-Peter Zeitinger, founder of the German ProCredit juggernaut, which now operates in Eastern Europe, Latin America, and Africa, echoes Solorzano, calling his loans "information-based credit." ${ }^{20}$

Those phrases accentuate the contrast with conventional lending. But from the standpoint of group lending, individual lending looks relatively conventional. Indeed, there is no sharp line between individual microlending and more-conventional small business lending. Loan officers do assess clients' business operations with an eye toward current earnings and potential earnings if the proposed investment is made. They do often accept or require physical collateral, mortgages, or credit scoring. Bank Rakyat Indonesia (BRI), one of the world's largest microlenders, only lends individually, and requires titles to land, buildings, motorcycles, or other property as collateral. ${ }^{2 \mathrm{I}}$ Given the low market value of most assets pledged, however, MFIs prefer to use such collateral as a threat rather than a way to cover losses from default. The incentive to repay is rooted in the high replacement cost of the pledged asset to the household and by the borrower's desire to avoid the social shame of having his or her household items seized in front of family and neighbors. As Solorzano puts it, FINDESA "doesn't want a used, rusty refrigerator. We lose twothirds of the value when we seize collateral." ${ }^{12}$ It is only when lending to small or medium enterprises that loan sizes may be large enough for collateral to become valuable in the traditional sense.

\subsubsection{A conceptual framework for microcredit methodologies}

This bare-bones introduction to microcredit offerings does not convey their full complexity, variety, and dynamism. Nor does it touch on other financial services, including savings, insurance, and transfers, that MFIs are increasingly offering. It suffices, however, to ground an important observation about the nature of the challenge for microfinance practitioners, and their response to the challenge. Specifically, the dominant microcredit products can be seen as arrayed along a spectrum. At one end of the spectrum, loans are smaller, more costly to provide relative to loan size, and are only made practical by shifting certain tasks onto borrowers. At the other end, loans are larger, cheaper for the MFI to administer, and more convenient for the customer. They also go to the relatively better-off.

In general, lenders face three costs: financial (costs of capital), default (which appears in accounting through loan loss provisioning), and operational or transaction costs. The last two are more under the MFI's control, and the last is disproportionately high for small loans, thus dominating in microfinance. A \$roo loan does not cost ten times less to administer than a \$r,o०o loan. So the poorer the borrower, and the smaller the appropriate loan, the higher the cost per 
dollar lent. Figure $\mathrm{I}$, based on data from MFIs reporting to the MicroBanking Bulletin (MBB) for 2004, shows that village banking has the highest costs relative to the amount lent while individual lending has the least. To rein in costs per loan and make small loans practical, lenders must squeeze operating costs where they can and shift costs that remain onto borrowers. Figure 2 shows the result: on a per-loan basis, village banking MFIs keep their spending the tightest, although its delegation of responsibility is also a form of empowerment. Solidarity group lending puts somewhat fewer costs onto borrowers, since loan officers work directly with all clients and shoulder some responsibility for collection from borrowers having difficulties. It compensates by imposing more routine on the credit relationship, in order to speed transactions. Individual microlenders absorb much more of the underwriting, monitoring, and enforcement costs themselves. In viewing these Figures, bear in mind that all but a core of dedicated povertyfocused solidarity lenders have moved into the mixed individual-solidarity category, and may not be representative of solidarity lending per se. For example, the true typical loan size for solidarity lending is probably between those shown in Figure 2 for solidarity lenders and mixed ones, and above that for village banking, as is the case in a 1999-2002 sample reported by Robert Cull, Asli Demirguc-Kunt, and Jonathan Morduch. ${ }^{23}$

Important subcomponents of the potentially transferable operating costs are for underwriting (loan approval), monitoring of use and repayment, and enforcement. ${ }^{24}$ Group lending shifts these responsibilities onto borrowers. Borrowers in turn will only accept them to the extent that they need capital and have no better alternative. And it is the poorest who have the fewest alternatives. The less-poor, on the other hand, will opt for individual lending and larger loans. (See Figure 3.) This pattern is of course universal in service businesses: the less you are willing to pay, the less you are catered to.

The bottom line in the bargaining between lenders and borrowers are that individual lending is unattractive for lenders at the low end of the loan scale as too expensive, while group lending is unattractive to borrowers at the high end as too burdensome. As a result, village and solidarity banking serve the poorest while individual lending goes more to the less poor. Table $\mathrm{I}$ has the numbers behind these charts.

These data suggest that commercially successful microfinance programs are designed not just to maximize direct impact on their clients. It is not simply the case that village banking, say, is more prevalent in rural Mexico than individual microcredit because village banking, with its emphasis on empowerment, happens to do a better job of helping rural Mexicans. Rather, in a successful MFI, the choice of basic product type is an adaptive responsive to what could be called the business environment. Central to the adaptation is a choice about how much cost to ask clients to bear. 
Figure 1. Expenses as a share of outstanding loans by lender type (median), MicroBanking Bulletin survey, 2004

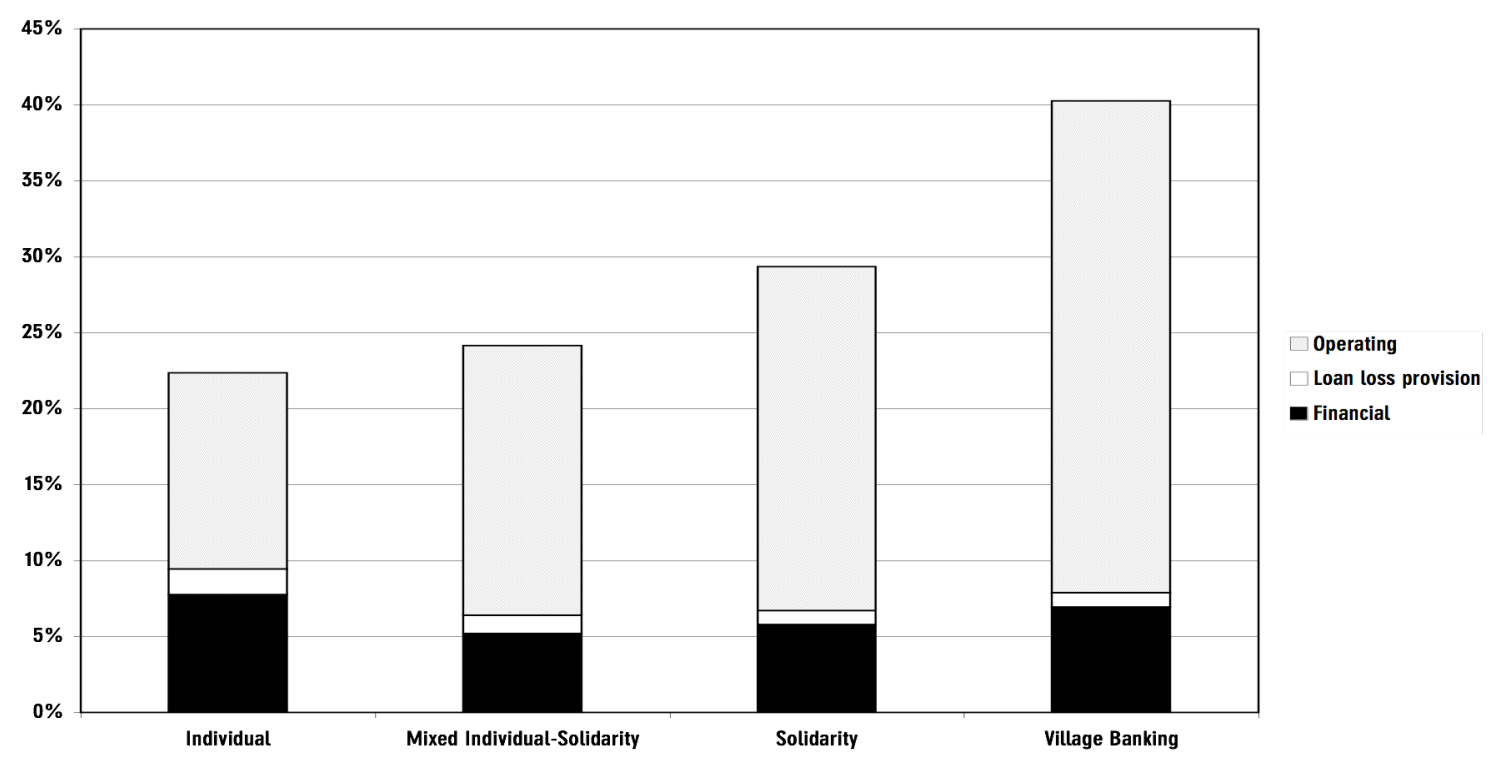

Figure 2. Expenses per loan by lender type (median), MicroBanking Bulletin survey, 2004

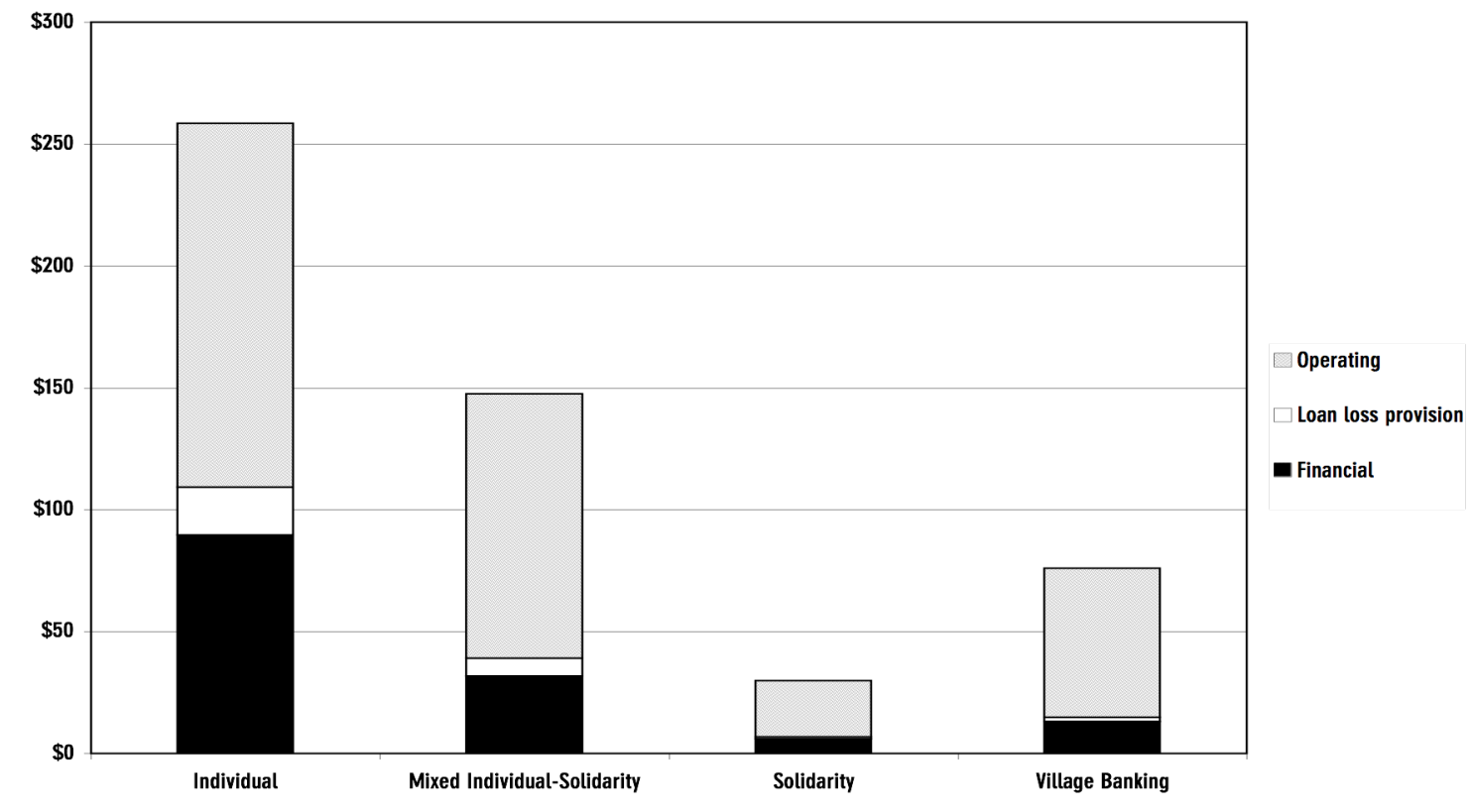


Figure 3. Loan sizes in dollars and fraction of GNI/capita by lender type (median), MicroBanking Bulletin survey, 2004

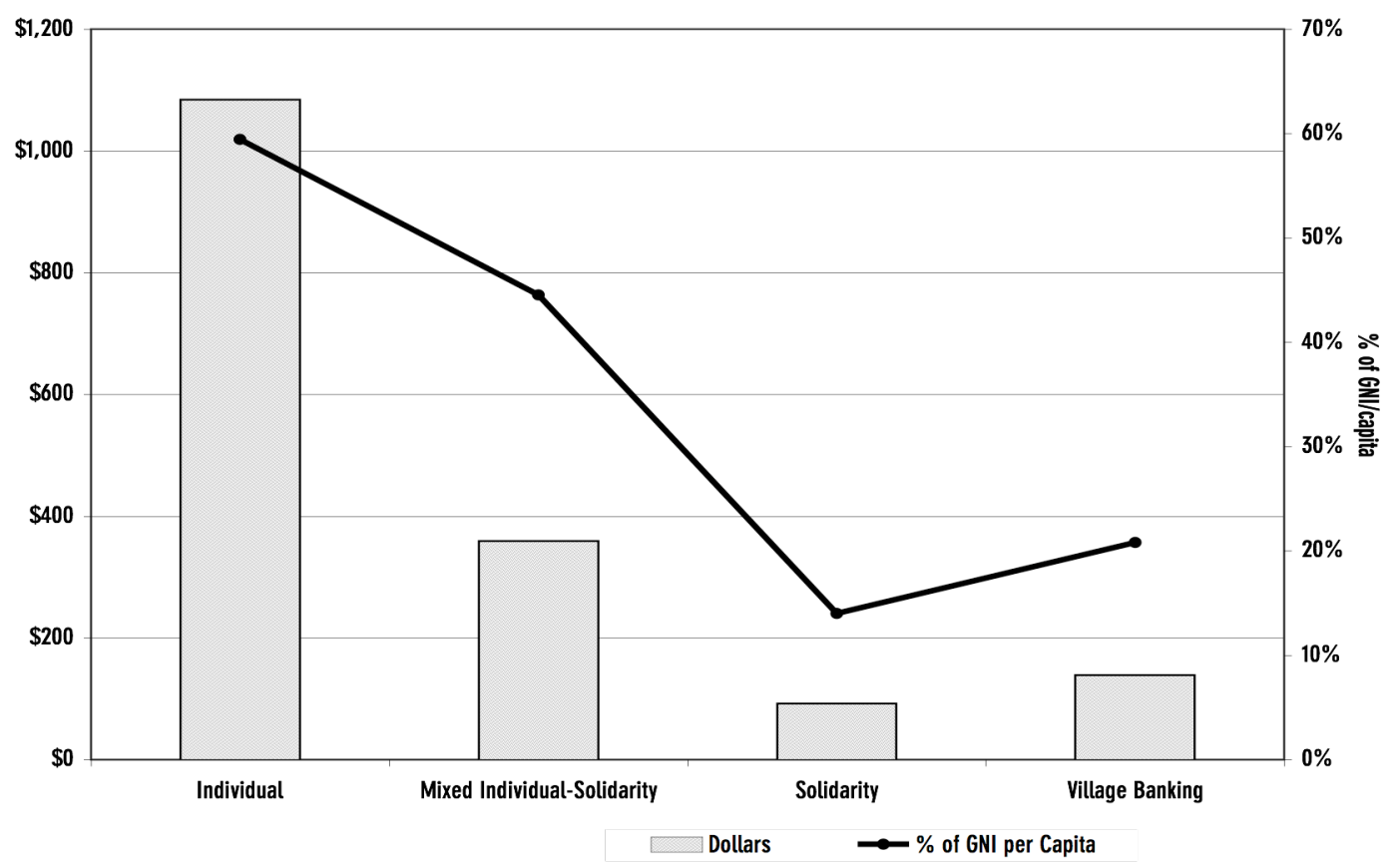

Table 1. Characteristics of MFls reporting to the Microbanking Bulletin survey, 2004 (medians)

\begin{tabular}{lr|rrrr|rr|} 
& & \multicolumn{4}{|c|}{ Expenses (\% of assets) } & \multicolumn{3}{c|}{ Average loan balance per Borrower } \\
\cline { 3 - 9 } Type & $\begin{array}{c}\text { Number in } \\
\text { sample }\end{array}$ & Financial & $\begin{array}{c}\text { Loan loss } \\
\text { provision }\end{array}$ & Operating & Total & Dollars & \% of GNI per Capita \\
\hline Individual & 104 & 7.8 & 1.7 & 12.9 & 24.6 & 1,084 & 59.5 \\
Mixed Individual-Solidarity & 132 & 5.2 & 1.2 & 17.8 & 25.9 & 359 & 44.6 \\
Solidarity & 32 & 5.8 & 0.9 & 22.7 & 30.3 & 92 & 14.0 \\
Village Banking & 34 & 7.0 & 1.0 & 32.4 & 39.8 & 139 & 20.8 \\
\hline
\end{tabular}

'Previous columns do not sum to totals because median totals differ from total medians.

Source: MicroBanking Bulletin: 2004 Benchmarks, available at

http://www.mixmarket.org/medialibrary/mixmarket/2004_MFI_Benchmarks[2].xls.

\subsection{Aspects of product design}

HAVING INTRODUCED THE major product methodologies and a way to think about them, we embark on a more thematic survey of product design, still with an interest in choices that have been made that advance microfinance as a business proposition. Although this is not our focus here, some of these design choices, such as targeting women, may also directly serve social ends.

The business problem for MFIs can be stated most broadly as finding ways to keeps costs near or below revenues - but that generalization is vacuous and needs unpacking. The real challenges include: 
- Building volume. The ability to spread fixed costs of lending operations over a large portfolio helps lenders reduce their operating costs as a percentage of assets (outstanding loans).

- Keeping loan repayment rates high. Searching for defaulters and cajoling or threatening them into repaying is extremely expensive for small loans. Moreover, especially with group lending, default can spread, since people will ask, "Why should I repay if she did not?" This contagion effect is a downside of the intimacy of group lending; it puts a premium on near-perfect repayment rates.

- Retaining customers. Even the most efficient MFIs find it hard to cover costs on the smallest accounts; most need to cross-subsidize them from larger loans to clients who have proven their ability to pay. This makes it essential for MFIs to grow with their customers, moving to progressively larger accounts.

- Charging rates commensurate with costs. High interest rates are a well-known and controversial aspect of microfinance. But MFIs cannot succeed in the commercial sense if they do not cover their costs, or at least come close, so that subsidy dependence does not limit scale.

- Compliance with prudential regulation. Banking regulations have much to say on what financial institutions can and cannot do. Most MFIs, for example, can only take deposits from people who are borrowing even more from them at the same time.

- Minimizing scope for fraud. In large organizations composed of small branches physically linked by weak transportation and communications infrastructure, monitoring branch activities to prevent internal fraud is a major challenge, all the more so in countries with a culture of corruption in business and government.

The remainder of this section explores ways that MFIs have met these challenges. Two points should be borne in mind throughout. First, none of the strategies discussed is truly essential for sustainability: for every strategy, there are MFIs that eschew it yet succeed. Second, some were developed or copied by people who saw them as primarily serving a social mission. Through an evolutionary process of selection, however, those strategies still came to the fore for what were essentially business reasons. We suggest below, for example, that the focus on women in group lending arose through a process of experimentation in the late 1970 s at what became the Grameen Bank, as the institution discovered that women were easier to work with than men in rural Bangladesh. Some Grameen imitators are probably unaware of this history and lend to women purely out of reasons of social mission. ${ }^{25}$ Similarly, the dominance of credit itself seems to have arisen for practical reasons, yet some now call it a human right. ${ }^{26}$

\subsubsection{Credit versus voluntary savings}

Stuart Rutherford eloquently reminds us that "financial services for poor people are largely a matter of mechanisms that allow them to convert a series of savings into usefully large lump sums. ${ }^{127}$ Most poor people do set aside money, if in small amounts and irregularly, not because they have income left after meeting basic needs, but because their needs include larger purchases 
like medicine or clothing or spending at religious and family ceremonies that cannot be matched by the uneven trickle of income. Indeed, while the capacity of the poor to borrow and save may be surprising, their need to do so is greater than it is for the better-off. Precisely because their incomes are tight, ways to manage mismatches between often-volatile incomes and consumption can be a matter of survival.

Saving and borrowing, though seemingly opposite, are actually similar in helping households convert small payments into larger lump sums. ${ }^{28}$ Which is better depends on the use for which the lump sum is needed. If funds are required for household consumption smoothing in the presence of volatile income, then savings may be a cost-effective, less risky alternative to borrowing. If, on the other hand, funds are needed for investment, then credit provides quicker income gains.

Microcredit is commonly defined as a vehicle for microenterprise. Numerous stories of clients who have struggled out of poverty by their own entrepreneurial efforts have been documented. Assuming that microcredit finances microenterprise, then the willingness of the poor to keep borrowing at high interest rates suggests that rates of return on borrowers' projects are even higher. In fact, microcredit often finances consumption. It is generally accepted that many poor people borrow at even higher interest rates from moneylenders for consumption, so willingness to pay cannot be assumed to demonstrate profitability of investments. In practice, MFIs, like moneylenders, require high-frequency, regimented payments on a schedule unrelated to the gestation periods of investments. And when MFIs do directly assess repayment capacity, they do so based on current income and assets rather than assumed returns from the proposed investment. Since money is fungible, it can appear to go for one purpose while actually serving another. If a borrower would have used her own funds to invest in a cow but instead takes out a loan for that purpose, then what the loan really does is let her put her own funds to some other, new purpose. In general, no sharp line separates the financial affairs of a poor household from the enterprises its members pursue. MFIs cannot expect their loans to only finance investment. Direct surveys of clients reveal a wide spectrum of uses. ${ }^{29}$

Though contrary to the original spirit of microenterprise lending, borrowing to finance and smooth consumption can be a very good thing. ${ }^{30}$ In a study of a payday lender in South Africa (not ordinarily considered an MFI, but analogous in offering short-term loans without collateral to poor people), Dean Karlan and Jonathan Zinman find that extending credit to applicants who would otherwise just miss qualifying reduces the number of times someone in the family goes to bed hungry. ${ }^{3 \mathrm{I}}$

But to the extent that clients borrow to smooth consumption, voluntary savings seemingly offers a viable alternative, since it equips poor households to manage income volatility without the stress of debt. Ideally then, clients should have opportunities to save along with opportunities to borrow. To quote Malcolm Harper, chairman of India's Basix Finance Group, "most people, including the poor, want to have savings nearly all the time and to be in debt less frequently." ${ }^{22}$

Researchers have confirmed that even the poorest households are willing and able to save, and that the existing informal methods (jewelry, cash-under-the-mattress, rotating savings and credit associations (ROSCAs), etc.) do not provide sufficient means for them to save. They carry considerable risks, of theft, inflation, fall in asset prices after natural disasters, and so on. ${ }^{33}$ Also, 
while the ability of the poorest to profitably utilize credit for microenterprise is still an open empirical question, the desirability of promoting savings to act as buffers against income volatility, especially for households for whom such volatility can threaten survival, cannot be denied. $^{34}$

Why then has the microfinance movement emphasized credit over voluntary savings? From the point of view of the MFIs, credit is more practical in several ways. First, there are, appropriately, fewer regulatory barriers to lending than to taking deposits. A small NGO cannot and should not easily become a bank (though the requirements for getting a banking license are arguably too stringent in many countries, as section 3.2.5 discusses). Second, and in the same vein, it is harder for an MFI to persuade people to trust it with their savings than to borrow from it. Third, for lenders, the regularity and uniformity of repayment schedules speeds transactions at weekly meetings, and may also increase total financial flow. Finally, credit imposes discipline and routine, which encourages clients to repay more regularly than they might save.

From the perspective of the borrower, the discipline provided by regular payments can be useful in maintaining commitments to put aside funds for specific purposes when faced with competing uses and demands from other family members. It is for this reason that popular savings schemes such as rotating savings and credit associations rely on regular, compulsory contributions. ${ }^{35}$ Joining the ROSCA is a voluntary decision, but once in, members have to meet fixed payments, and, much like the loan repayment schemes, both shame and loss of access to future finances provide the motivation to stick to the payment schedule.

A final factor in favor of credit is that credit programs are more investible from the point of view of public and private donors and other investors. Ironically, the greater need of credit programs for outside capital may make it easier to attract it from official donors and socially minded investors, who often feel a perverse career incentive to disburse larger amounts with less staff time. With the same effort, a donor could place \$roo million in a lending program or \$IO million in a savings program.

All that said, the dominance of credit appears to be waning among MFIs that serve people at the poverty line, as opposed to well below it. Of the 302 MFIs included in the $2004 \mathrm{MBB}$ data, $89(29 \%)$ reported voluntary savings in excess of $20 \%$ of total assets. This figure will probably rise as more microfinance organizations become banks, and as more banks enter microfinance. Foremost among the savings-taking institutions is BRI, whose Unit system held \$3.6 billion in savings for 32.3 million people at the end of 2005 , ten times the number who had loans. ${ }^{36}$ Notably, BRI is a century-old institution, government-run at the birth of its microfinance program in the mid-ı980s, and now government-controlled, though partly privatized. It never faced prudential barriers in taking microsavings, nor needed outside capital. The ProCredit group, which provides "banking for ordinary people," not necessarily the poorest, now boasts \$r.7 billion in deposits against $\$ 2$ billion in outstanding loans. ${ }^{37}$ In Bangladesh, in a startling development, Grameen saw its savings "portfolio" exceed its loan portfolio at the end of 2004. The icon of microcredit now does more savings than credit. However, the growth appears driven by the popularity among less-poor Bangladeshis of its Grameen Pension Savings (GPS) commitment savings product, which pays out after five or ten years at an annualized rate of I $_{2} \%$. It is not yet clear that this rate, and Grameen's shift to savings, is sustainable. One important 
example of savings emphasis for the very poor operates in the slums of Dhaka: SafeSave's workers visit clients daily in their homes to collect deposits as small as I taka (I.5 cents). But such services have yet to reach the scale of group lending for the very poor.

Several MFI heads interviewed for this paper said they preferred savings as a source of capital because it comes with fewer strings attached and less managerial hassle than donor and investor money. The biggest constraint to mobilizing savings may not be the shortage of savers in poor communities, but rather the ability to lower transaction costs of small deposits and manage liquidity. It is in the latter that downscaling banks (traditional banks moving into microfinance) might have an advantage over small-scale MFIs. Apart from the regulatory issues regarding deposit-taking institutions, such as minimum capital requirements, which tend to favor a larger scale of operations, the ability to manage liquidity requires the type of back-office support and expertise that is not otherwise necessary for credit-only organizations. As early as its sixth year of operation, in 1989, BRI achieved self-sufficiency in funding: it mobilized \$533 million in savings against a loan portfolio of \$47 million. Deposits continued to increase relative to loans in subsequent years, with an average deposit-to-loan ratio of almost 2:I, and the excess savings were channeled into loans to larger corporations. ${ }^{38}$

\subsubsection{Dynamic incentives}

Almost all MFIs start small with new clients, offer bigger loans if the first ones are repaid, and so on. Group lenders, in particular, follow highly standardized and rigid loan ladders which specify a maximum loan size for each loan cycle. Economists say that these expanding cycles create a "dynamic incentive" for clients, because what a client does today affects her options tomorrow. Jain and Moore point out that in solidarity lending, staggering the entry of group members into the lending cycle amplifies dynamic incentives. For at any given time, at least one member is just a few months away from repaying one loan and getting a bigger one. She has a particular incentive to keep the group going by making sure all her fellow members remain in good standing.

Progressive lending, by gingerly testing the waters with a new client, can also be viewed as another way to winnow out risky customers. As a rule of thumb, because of economies of scale in loan size, MFIs do not fully cover their costs until the third or fourth loan to a client. ${ }^{39}$ But progressive lending is also worrying, in that for borrowers who lack the capacity to repay, it may create a powerful incentive to go to a second lender - a moneylender or another MFI-for a bridge loan, to be repaid as soon as the new, larger loan comes through from the first lender. It can thus feed a cycle of debt, concealing, deferring, and exacerbating the ultimate confrontation with trouble. Successful MFIs therefore cannot rely on dynamic incentives alone to keep the portfolio healthy, but must also use other mechanisms, whether the "shame factor" of group lending, networking in the community, or ongoing assessment of repayment capacity to check unsustainable loan growth.

More generally, lenders create dynamic incentives whenever they offer better loan terms down the road as a reward for on-time repayment today. In another experiment in South Africa, for example, Karlan and Zinman found that offering a borrower a lower interest rate on his next consumer loan had a huge impact on repayment of the current one. ${ }^{40}$ 
Individual lenders have harnessed dynamic incentives most effectively because they do not have to deal with the restrictive loan ladders of group lending and can more freely tailor individual loans in terms of lending periods, interest rates, and repayment schedules. And in scaling up, they do not need to worry about imposing inordinate risk on poorer, jointly liable fellow borrowers.

\subsubsection{Lending to women}

The face of microfinance is usually a woman's. Some MFIs, like Crecer in Bolivia and Kashf in Pakistan, lend exclusively to women. ${ }^{4 \mathrm{I}}$ But while $89 \%$ of the borrowers of the median solidarity group lender and $94 \%$ of the village banking lender are female (in the $2004 \mathrm{MBB}$ survey), only $54 \%$ of borrowers of the median individual lender are. (See Figure 4.) Why the gender split between individual and group lenders? One reason may be that it is a matter of mission. Povertyfocused, group-oriented MFIs target women with their tiny loans because their oppression only compounds their poverty in limiting options in life. And women are more likely to channel the support to their children. The larger loans of individual lenders may go more for enterprise investment than consumption smoothing, and men dominate in the sphere of commerce.

Figure 4. Share of borrowers who are women by lender type (median), MicroBanking Bulletin survey, 2004

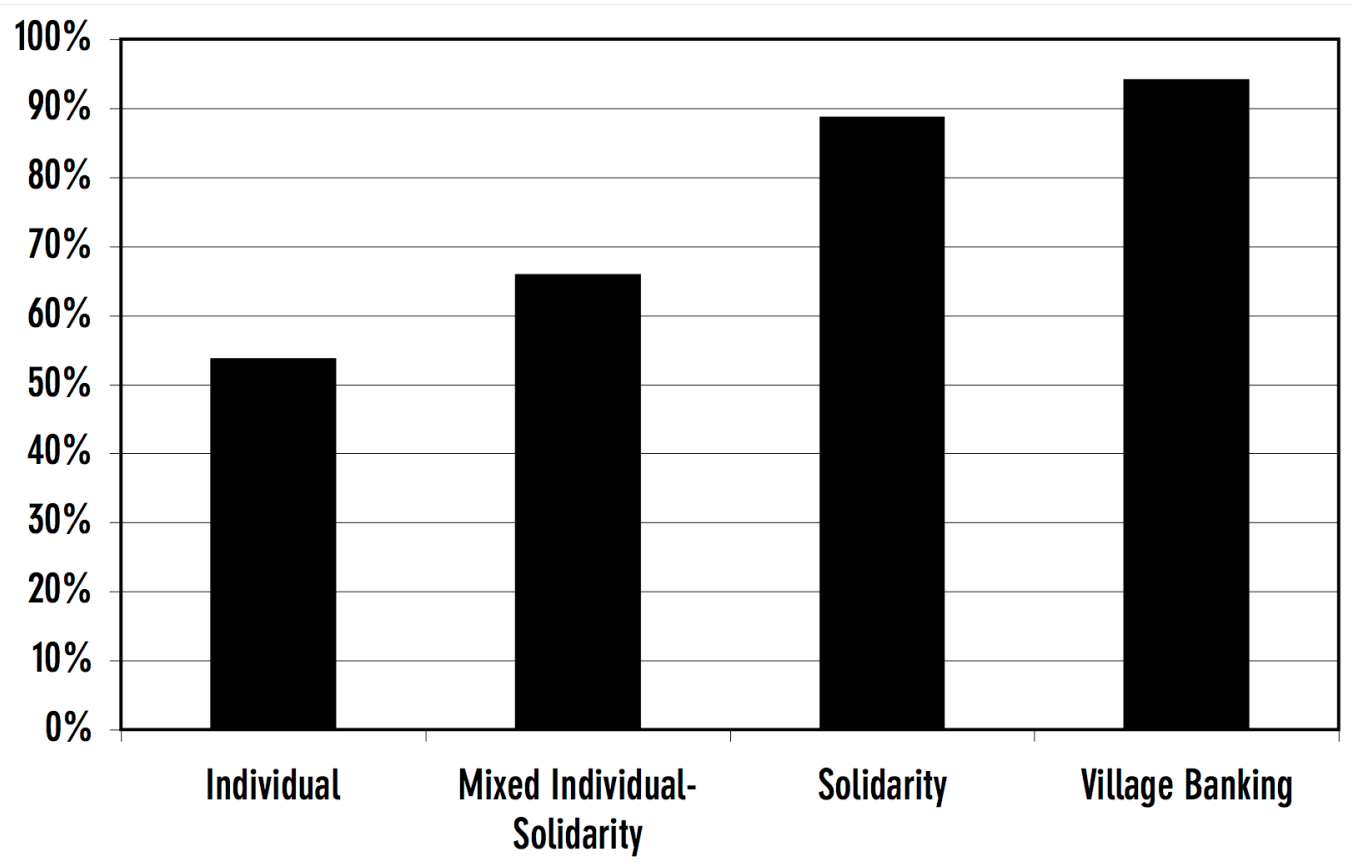

However deserving and appropriate women may be for microcredit, this is not the only reason they have gotten more of it. MFIs that target women draw inspiration from Grameen. But in Grameen's early years, men actually dominated. As Yunus and his team refined the methodology, they shifted toward women. The focus became official in $1985 .{ }^{42}$ (See Figure 5.) BRAC, the giant Bangladeshi NGO, moved on the same path after it entered microcredit. ${ }^{43}$ After 13 months of 
field work in Bangladesh, anthropologist Aminur Rahman of the University of Manitoba came to the conclusion that the immediate reason for the move toward women was practical. For cultural reasons, women were more sensitive to protecting the reputations of their families, perhaps precisely because of their relative lack of power. As a result, in rural Bangladesh, at least, they repay more reliably. One loan officer explained to him that, "In the field it is hard to work with male members. They do not come to meetings, they are arrogant, they argue with the bank workers and sometimes even threaten and scare the bank workers." Women, he was told, are more vulnerable and submissive, and less mobile, thus easier to track down if they do not pay. The very attractiveness of the public meetings for women largely barred from public fora may give MFIs leverage. ${ }^{44} \mathrm{~A}$ woman put it to Rahman this way:

When a woman fails to make her instalment [sic] on time, she experiences humiliation through verbal aggression from fellow members and bank workers in the loan center. Such humiliation of women in a public place gives males in the household and in the lineage a bad reputation (durnam). In an extreme case peers may take the defaulter to the bank office. For a man, if he is locked inside the bank building for several days it would mean almost nothing to other people in the village. But if this happens to a woman then it will bring durnam to her household, lineage and village. People in other villages will also gossip about it. ${ }^{45}$

Reinforcing this picture is Rahman's finding that $60 \%$ of the women in his sample joined Grameen at the request of their husbands, and another $12 \%$ did so at the request of other men. Then, about $60 \%$ of the time, men in the household decided how the loans were used. In another sample of microcredit borrowers in Bangladesh, not just of Grameen, Anne Marie Goetz and Rina Sen Gupta found that $63 \%$ of borrowers had partial, very limited, or no control over the use of loan funds. ${ }^{46}$

None of this proves that microfinance does not help women. That women are repaying year after year hints that they use the money more responsibly and productively than men on average. That women have been gathering week after week to conduct business in group meetings is changing Bangladeshi norms about women's use of public space. That $37 \%$ of women did control loan use may be a victory for female empowerment. But the data also show that women are often conduits for loans to men. MFIs' preference for working with and through women strongly suggests that they do so in part because it helps them solve a business problem. "It is not a philosophical thing; it is very practical," says Carlos Labarthe, co-CEO of Mexico's Compartamos. ${ }^{47} 98 \%$ of Compartamos clients are female. ${ }^{48}$ So does the minimal gender tilt among individual lenders. And as we emphasized at the outset, the business logic can operate even when MFI managers target women purely for reasons of direct impact. 
Figure 5. Share of members who are women, Grameen Bank, 1976-2005

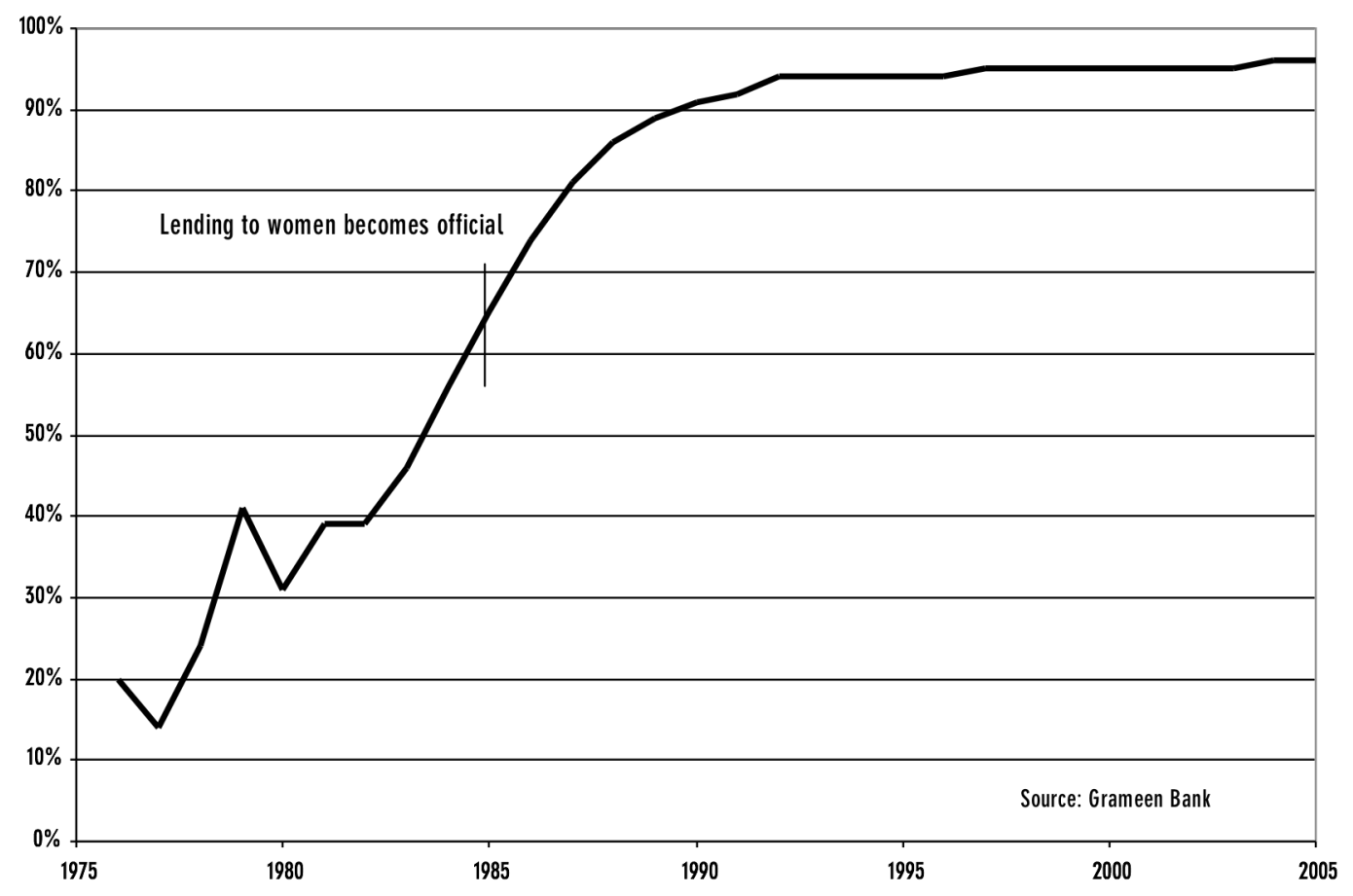

\subsubsection{Frequent transactions and short loan terms}

Borrowers use microcredit for a wide variety of uses, from financing weddings to paying for dayto-day consumption needs to investing in productive activities. Investment activities in turn range from substituting for high-interest supplier's credit, which can pay dividends in a single day, to buying calves that will not generate returns for months. Yet microloans almost always require frequent, regular payments that start immediately after disbursement. And they usually mature with six or twelve months. Microcredit, then, is poorly matched to many common investments.

Clearly the frequent payments and short terms are pragmatic. Allowing microcredit borrowers to pay all principal and accumulated interest in a single transaction years after disbursement would invite disaster, just as it would for home mortgages. Much of the discipline that one hopes for from a loan would evaporate. Likewise, the need to immediately repay filters out prospective clients in the same way as forced savings. Thus, microcredit often restricts itself to those who already have enough income to repay the loan from other sources, regardless of the success of any new enterprise they pursue. ${ }^{49}$ Again, we see MFIs designing a structure that selects less- risky borrowers and elicits compliance from them.

\subsubsection{Matching rates to costs}

The microfinance world was once intensely divided over the question of whether interest rates ought to be subsidized, to help the poorest, or not, so that MFIs can grow faster. The debate cooled somewhat as the icons of poverty focus, such as Grameen, reached operational self- 
sufficiency. We do not take a position on that question. Rather, we merely observe that if the objective is commercial viability - or being close enough to it that the need for subsidy does not throttle growth - rates must be high enough to cover most or all costs. In accepting this mathematical reality, we recognize that there is such a thing as interest rates that too are highthough defining the threshold is both difficult and beyond the scope of this paper.

How high the interest rates actually are in any particular case can be difficult to ascertain. Indeed, one has to conclude that one common design strategy is to obscure the true cost. Perhaps for simplicity, MFIs often state their interest rates on a "flat" basis- that is, relative to the original loan amount. But if an MFI makes a \$roo loan to be repaid in equal installments over 50 weeks, then over the course of the year the average balance is only about $\$ 50$. Thus the effective interest rate, relative to the average balance, is about twice what it appears to the naïve. In addition, MFIs may charge origination fees, force savings that earn below-market interest or none at all (section I.2.7), or sell credit life insurance at high prices (section 1.2.8). The best, systematically collected measure of the interest rate, then, may be the gross portfolio yield, an MFI's ratio of income on loans to loans outstanding. In the 2004 MBB sample of 302 MFIs, individual lenders reported a gross portfolio yield of $32.0 \%$ at the median $(24.9 \%$ after adjusting for inflation), while solidarity lenders charged $41.7 \%$ (32.7\% after inflation) and village banks $48.9 \%$ (39.1\% after inflation). These figures understate the actual charges to the generally slight extent that arrears reduce yield. Since they are medians, half the solidarity lenders earn more than 4I.7\% and half the village banks earn more than $48.9 \%$.

Of course, raising rates does not automatically improve financial performance, since high prices can deter customers. Rajeev Dehejia, Heather Montgomery, and Jonathan Morduch confirmed that principle for microfinance by studying how demand for credit from SafeSave varies with the interest rate. (SafeSave is mentioned above in section I.2.I. It lends as well as takes deposits.) The researchers found that a $\mathrm{I} \%$ increase in interest charges (not a I percentage point increase) reduced uptake of credit by $0.25 \%$ in the short run and $1.18 \%$ in the long run..$^{\circ}$ Moreover, higher rates can exacerbate a form of adverse selection. As the rate goes up, potential borrowers with safe, predictable investment plans drop out because they know they will not be able to earn enough to cover the interest charges. That leaves a pool of clients with riskier plans, who have a shot at covering the interest but also greater chance of failure and default. ${ }^{5 \mathrm{I}}$

Given the contradictory effects of raising rates, the overall effect is an empirical matter. A separate study by Robert Cull, Asli Demirgüç-Kunt, and Morduch finds that within the observed range of variation for individual lenders, higher rates do correlate with greater financial selfsufficiency. Notably, this result combines with the study just cited to demonstrate that the feared trade-off at the heart of the traditional debate over interest rate policy, between outreach and financial viability, is real. Meanwhile, Cull, Demirgüç-Kunt, and Morduch find no relationship between interest rates and financial returns among group lenders. It may be that the group lender sample is too small to pick up such effects. Or the low-income customers of group lending may be more sensitive to interest rates, so that increases in revenue per client are offset by loss of clients. Or more group lenders may be heavily subsidized, thus insulated from market forces, so that income from higher rates is dissipated by administrative inefficiency. Overall, higher rates do not appear to burt financial self-sufficiency of either individual or group lenders 
within the observed range of variation. But they do not appear to help group lenders' finance on average either: the rise in income per client and the drop in clientele roughly cancel out. Where changing rates does not contribute much to commercial success, MFIs have to focus all the more on the cost side to achieve self-sufficiency.

\subsubsection{Limited product offerings and streamlined procedures}

An unfortunate side-effect of frequent transactions is high administrative burden. It is therefore imperative for MFIs to streamline transaction processing. One way to do this is to limit field officer travel time per client. In urban areas such as the Dhaka slums where SafeSave operates, it is practical for field workers to go door to door; SafeSave reports that its officers visit up to 200 clients a day. ${ }^{52}$ Field workers for individual lenders in urban Latin America also typically spend much of their time visiting clients where they live and work. But in somewhat less-dense areas, most MFIs insist that clients come partway to the loan officers, through regular meetings. Thus, in addition to making banking a public event, the meetings facilitate mass production. A group field worker can bicycle into a village, process a large number of transactions, and move on. In Bangladesh, workers follow highly regimented schedules, typically visiting two to three centers each morning to manage the weekly meetings. The loan repayments and savings collected at the meeting are taken back to the branch office at noon, where the worker logs all the transactions, leaving enough time in the late afternoon to follow up on either new group formation or members with payment arrears.

If each center has $15^{-} 40$ borrowers and meets weekly, each loan officer can manage at least 150 clients ( 15 clients $\times 2$ centers $\times 5$ days) or, use midpoints the $2^{-}-3$ and $15-40$ ranges, 344 clients $(27.5$ $\times 2.5 \times 5$ ). These estimates are comparable to the medians in the $M B B:$ in 2004 , village banks reported an average of 367 borrowers per loan officer and solidarity group MFIs had 287 borrowers per loan officer. (See Table 2.)

Table 2. Borrowers per loan officer by lender type (median), MicroBanking Bulletin survey, 2004

\begin{tabular}{lr|r} 
& Number in sample & Borrowers per loan officer \\
\hline Iype & 104 & 209 \\
Mixdividual Individual-Solidarity & 132 & 220 \\
Solidarity & 32 & 255 \\
Village Banking & 34 & 307 \\
\hline
\end{tabular}

Source: MicroBanking Bulletin: 2004 Benchmarks, available at http://www.mixmarket.org/medialibrary/mixmarket/2004_MFI_Benchmarks[2].xls.

Another way to keep transactions efficient is to limit the diversity of product offerings. This is one reason why loans tend to have inflexible repayment schedules, and why associated products such as forced savings and credit life insurance tend to be formulaic too. It also explains why 
MFIs have found it difficult to offer transaction accounts (like checking accounts) which give the client control over the timing and size of transactions.

Vikram Akula, who founded SKS Microfinance in India after several years observing self-help groups and the Grameen Bank, sees his company's edge as being in transactional efficiency. SKS makes sure all loan payments are multiples of 5 rupees, the smallest bill, and accepts no coins. ${ }^{53}$ Loan officers enter meetings with pre-printed, computer-generated lists of expected transactions. Transactions are quickly logged into a computer database. The uniformity in process makes it easier for managers to monitor the data in order to detect irregularities and send in "SWAT teams" to handle them. (See section 2.5.) Irregularities can signify trouble or innovation on the ground that should be learned from. ${ }^{54}$ SKS holds no monopoly on these practices; Bangladesh's ASA is also noted for its regimentation and efficiency. It is noteworthy that both MFIs are among today's fastest-growing.

As with the dominance of credit over savings, which in a sense is another example of limiting service diversity, here too there are exceptions to the trend. Grameen II has brought a wider diversity of services, in no small part a response to competition, which shifts power to the client. So far, Grameen's loan officers appear to be handling the complexity. ${ }^{55}$ SafeSave dedicates itself to serving the customer through flexibility, letting them decide how much to save each day.

\subsubsection{Forced savings}

A common element in classic solidarity groups and village banking is compulsory, or "forced," savings. Forced savings are collected during the group meetings, usually pay no interest, and cannot be withdrawn until the member exits the group. In effect, they accelerate loan repayment so that toward the end of a loan cycle, the MFI is actually in debt to its clients. Compartamos collects I0 \% of each loan and FINCA-Nicaragua collects $32 \%$ of the individual loan as forced savings. Compartamos collected the savings when a loan is granted and returns them at the end of the loan cycle. FINCA-Nicaragua, has borrowers make the savings in equal installments at meetings and does not returned them unless the borrower exits the village bank. ${ }^{56}$ Both MFIs also have recourse to village bank forced savings in the case of loan default by a village bank member or if the entire village bank fails.

MFIs offer two main reasons for collecting forced savings: I) to serve as cash collateral for loans, and 2) to inculcate the habit and discipline of regular saving. From the way forced savings are actually structured, however, the collateral explanation appears most compelling. The habit and discipline of regular saving can equally well be inculcated by offering voluntary time deposit accounts (analogous to certificates of deposit), or by commitment savings accounts, where each client chooses to commit to depositing a fixed sum at regular intervals. If, however, forced savings are premised that the poor are unwilling to save unless forced, then this is clearly a false premise since ample evidence now exists that the poor are both willing and able to save.

The cash collateral motive does make sense. Forced savings reduce MFI financial exposure when a village bank or a solidarity group center ceases to function. Indeed, the threat of losing savings can deter such failure. The fact that MFIs often do not return forced savings till a member leaves the program thus makes business sense. Similarly, using forced savings to cover the missed payments of individual clients helps the MFI recover losses. And by making the entire 
group center or village bank share the financial cost of default, social pressure is exerted on clients to make timely payments and to offer cross-loans to each other to cover the shortfall when difficulties arise.

\subsubsection{Credit life insurance}

In addition to compulsory savings, some group lenders require borrowers to buy credit life insurance, which covers their debts if they die. Grameen Koota, a solidarity group MFI in India, has members pay a total of $2 \%$ of the loan amount in equal weekly installments into an "Emergency Fund" that is used to write off the outstanding loan balance if the borrower dies. In addition, \$II (Rs. 500) are paid to the family for funeral expenses if the deceased borrower had been with the MFI for less than one year, and double that amount for a longer membership period. $^{57}$

Like forced savings, credit insurance helps both clients and MFIs. It helps clients, of course, by reducing risk. It reduces risk for the group because the members are protected from having to choose between running after deceased's grieving family or covering the loss themselves. For the MFIs, it lowers the risk from death of borrower. It also earns fee income at low administrative expense. Indeed, Grameen Koota's $2 \%$ fee seems high when you consider that the break-even price of credit life insurance as a percentage of the loan balance, assuming no transaction costs, equals half the percentage of borrowers who can be expected to die during the loan repayment period. For example, if an MFI lends \$Ioo each to Ioo women and one can be expected to dieon average, half-way though repayment - then the loss would be $\$ 50$, or $0.5 \%$ of the $\$ 10,000$ total lent, and a $0.5 \%$ fee would cover insurance costs. Seen through this lens, the $2 \%$ fee on oneyear loans implies an expected death rate of $4 \%$ /year, which seems unrealistically high-or another way of raising the effective interest rate.

FINCA-Uganda, a village banking MFI, has pioneered a life insurance product in Uganda that seems more forthright, costing less and offering more in a riskier environment, where HIV prevalence is high. It began in 1996 in partnership with the American Insurance Group (AIG). FINCA-Uganda charges its clients I\% of the loan amount as the cost of insurance, of which half is paid to AIG and half retained by FINCA. In the case of the client's accidental death, not only is the outstanding loan is written off but the heirs receive a substantial \$IIOo. (If the death is not by accident, only the loan is written off.) There is a $\$ 600$ pay-out for the accidental death of a spouse, and $\$ 300$ for a child. ${ }^{58}$ The product turned out to be so profitable that by 2004 , AIG Uganda was selling credit life insurance through 26 MFIs in Uganda, Tanzania, and Malawi, and was projected to earn just under $\$ 200,000$ from the product, $25 \%$ of total earnings. ${ }^{59}$

\section{Management}

THE PREVIOUS SECTION surveyed how commercially successful MFIs design their products to solve the business problem of microfinance. Many of the choices they make, such as lending to women and requiring frequent repayments, are widely known and copied. Yet most microfinance organizations are small. Figure 6 dramatizes the skewed size distribution of MFIs by sorting them from smallest to largest and graphing the cumulative number of borrowers against size, 
using data from a survey by the Consultative Group to Assist the Poor (CGAP). ${ }^{60}$ The $1,8 \mathrm{r} 3$ smallest MFIs have Io million loan accounts while the remaining 73 have 40 million. ${ }^{61}$ That is, $3 \%$ of MFIs provide $80 \%$ of the loans.

Figure 6. Cumulative number of borrowers by size of lender, circa 2000

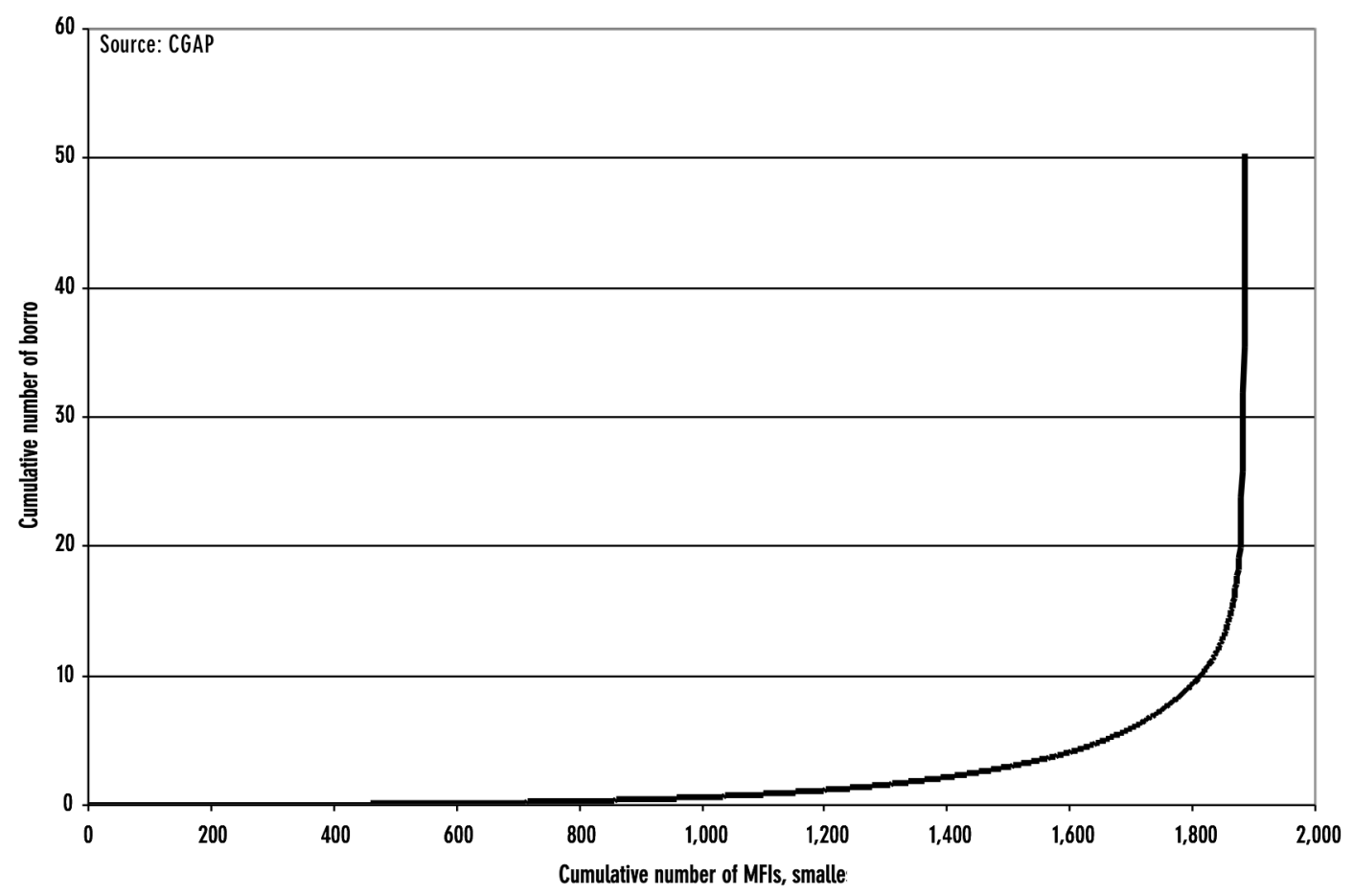

Why are so many MFIs so small and so few so large? The reasons are of three sorts. First, some MFIs do not prioritize internally funded growth. They may care more about keeping interest rates low to help the poorest, covering their losses with grants from public and private donors and leaving little in the way of retained earnings for expansion. ${ }^{62}$ Second, commercial success is about more than product design. MFI staff must also manage their organizations to deploy those products efficiently and on a large scale. This section is about what the commercially successful ones do. Finally, forces external to MFIs, such as macroeconomic stability, competition, and regulation, shape their prospects; these environmental factors are the subject of the next section.

Managing an MFI for commercial success involves all the usual challenges of business: defining job roles, hiring and training, monitoring employee performance, inculcating an appropriate culture to motivate staff, wooing investors, and more. Thus, to a significant extent, the keys to effective MFI management are universal to business. The nature of the product, however, influences specific management choices. This section will review broad management themes with an eye toward what they mean for microfinance. Much of the preamble to the review of product strategies above applies here: Most of the choices MFI leaders have made are intentional, and their astuteness is often underappreciated. In some cases, though, managers have developed or copied strategies unaware of their true contribution to the organization's sustainability, but in an 
evolutionary perspective they are business survival strategies nonetheless. Also, as before, exceptions prove the rule.

The overall picture that emerges is that the successful MFI is a decentralized organization. Retail units go to the customer and are the locus of production. They are where relationships with clients are made and maintained, where services are provided, where much learning should take place about the effectiveness of current approaches, where growth can occur through splitting of units. Excessive intervention in branch activities would slow and demoralize workers. Management - the center - picks and trains the right people; designs the products and the structure of local offices; gives them substantial operational autonomy for the sake of efficiency and morale; monitors their performance through strong management information systems (MIS); guides them by offering pay incentives and by inculcating a culture of service; and seeks to learn continually from experience in the field.

\subsection{Hiring, training, firing}

AS DEMONSTRATED IN Figure 3, operating expenses, as distinct from the cost of capital and loan loss provisioning, dominate the cost side of most MFIs' income statements. They in turn consist largely of the wages for field staff. That reflects the reality that microfinance to date has been a service delivered by people to people, unlike the increasingly automated financial services for the better-off. Since the field staff is the heart of any MFI, approaches to hiring, training, and even firing are leading determinants of success.

A common theme in MFI management is the need to break away from "business as usual." That can refer to conventional banking, seen as embodying attitudes and assumptions inimical to serving the poor. It can refer to the parent company in the case of a downscaling commercial bank. It can also refer to a national business culture pervaded by corruption, self-dealing, and politically directed lending. A nearly universal response is to hire young people. In Cambodia, for example, where corruption is prevalent in commerce and government, ACLEDA Bank says it is now the largest recruiter of fresh university graduates in the country. ${ }^{63}$ Young people have several advantages. They are cheap. They are more idealistic and malleable, so that the social mission of microfinance motivates them. They are more willing and able to spend hard hours on the "street." They are ready to live campus-style in remote areas.

Elisabeth Rhyne and Linda S. Rotblatt of Acción International wrote that "good field workers are made rather than found, but...a certain level of education and key personal and social traits are essential prerequisites." ${ }^{64}$ In fact, one way to paraphrase this is to say that good field workers are both made and found. Not everyone is cut out for the job. Some characteristics of the ideal candidate are subtly contradictory and not always found in the same person. For instance, on the one hand, to earn clients' trust and judge their reliability, field workers need good knowledge of local communities, best ensured by hiring right from those communities. The workers must also like working with people, especially people with difficult lives. On the other hand, MFIs are often in a position to skim the cream of local talent. They can choose workers who are better off than most of the clients, have climbed the social ladder through education, or have migrated 
from countryside to city - and may not want to look back. Susan Gibson, a microfinance training consultant, describes what she looks for:

When I interview people to run programs, I do not ever interview them in the office. When they come all [well-dressed,] I say, "Well, we're going to Coronation Market," (this is in Kingston, Jamaica). They look at you as though something is wrong with you. They say, "But there's crime down there," and I say "that's where we're going to do our microfinance program." You can save yourself an incredible amount of time, and you can also learn whether that person is well-suited to the job. So we will get on the bus; I would not even take them in a vehicle because I expect they will take the bus everyday. I want to see if they have bus fare. If they do not have it, they are not accustomed to taking the bus; we might have a problem right up front." ${ }^{15}$

So MFIs must strike a difficult balance, hiring educated young loan officers, often from a social class above their clients, who view their work as business and not charity, and yet who want to work with people less blessed. Gibson again:

The problem with a lot of microfinance programming around the world is that it comes out of a charitable mindset, and you are trying to get people who gave out blankets and food distribution to now make loans. It's not a good combination and in many cases, we have had to tell people, "you know, this is not for you." You cannot just convert people from a social service worker to a loan officer. It doesn't work. ${ }^{60}$

Cost also enters the mix of hiring considerations: workers with professional degrees or prior work experience are more expensive. As a result, a trade-off must often be made between skill and proximity to clientele, and how best to make it depends greatly on the lending methodology. Efficient solidarity group lending consists in no small part in implementing routines. That argues for less-skilled workers, closer in social class to the clientele. About $40 \%$ of SKS hires, for example, are children of clients, and few have any university education. ${ }^{67}$

But efficient individual lenders, as we will discussed, require more independent judgment on the part of loan officers, which is why their typical hires are college graduates. These workers must assess the quality of the information given by the client, which cannot be taken at face value even when supported by financial statements. Good individual loan officers develop indirect techniques for getting at the truth, such as asking borrowers about both the value and volume of their sales in order to see whether the implied price is realistic. Others can tell a lot about a retailer's business by scanning the merchandise on the shelves. ${ }^{68}$ Are the shelves empty or full, the products new or old? All this requires a habit of critical thinking, of generating hypotheses and testing them against evidence.

For effective MFIs, the tasks of finding and making good field workers intertwine. For no candidate is proved until he or she works in the field, and while some training can take place in the classroom, much is more effective on the job. This makes recruitment an intensive process that plays out over months. As of the mid-r99os, BancoSol in Bolivia put candidates through a battery of tests and interviews. At Grameen, between a third and fourth of new hires dropped out during the initial probationary period. ${ }^{69}$ Today, ACLEDA puts new recruits through three 
weeks of field and classroom training before deciding whether to channel them into group or individual lending operations. ${ }^{70}$

In addition to teaching products and procedures, training transmits a sense of mission, making employees feel that they are part of something larger than themselves. In our interviews with MFI directors about "secrets" of commercial success, one factor invariably mentioned was a shared sense of mission within the organization. Few large organizations anywhere are better positioned than MFIs to do it. MFI employees can take pride in their service to the poor and their professionalism in a milieu of corruption state-distorted financial sectors. Sense of mission motivates long hours. It also spreads excellence by encouraging workers to go beyond the written rules of their jobs - to do not just what they bave to do but what they can do to improve efficiency and serve the customer. Most employees work directly with dozens or hundreds of clients a day, so that the mission becomes concrete for them, as multitude of faces and families.

Serious investment in training is thus a hallmark of commercially successful MFIs. The regimen at the ProCredit group, an individual lender, includes five two-week sessions per year for the first three years. The company runs a training center near Frankfurt and is planning new ones in Ghana and Nicaragua. ${ }^{71} \mathrm{XacBank}$ in Mongolia maintains a training center with several full time staffers at its headquarters and uses distance learning technologies to reach its far-flung branches. ${ }^{72}$ FINDESA regularly sends employees to training seminars. ${ }^{73}$

A final note on personnel management is that effective MFIs need to be willing to fire, especially in the event of fraud. This can be especially difficult in rural East Asia, where cultural norms about the importance of saving face are adapted to preventing open ruptures. Historically, BRI in Indonesia has sought to avoid firings by transferring or demoting employees, but even it will terminate workers for poor performance when other options are exhausted-all the more a sign of excellence for its cultural difficulty. ${ }^{74}$

\subsection{Going to the customer}

POOR PEOPLE CANNOT afford to travel long distances to meet their bankers. Public transportation can be expensive and so is missing a day of work. Besides, their lack of knowledge of the formal financial system is a deterrent. A loan officer who comes to the village or neighborhood and transacts in public reduces the transaction costs for the borrower even as he demonstrates to neighbors that financial services are within their reach too.

From the lender's perspective, going to the customer helps build relationships, acquire information, speed transactions, and enforce compliance. Given the lack of public documentation of assets and income, and general lack of credit histories, the loan officer has to assess repayment capacity through indirect means: he can observe the lifestyle of clients, talk to neighbors about character and integrity, and visit business premises to ascertain repayment capacity. Even information regarding the drinking and gambling habits of clients can furnish clues about their default risk. FINDESA-Nicaragua loan officers drop by borrowing businesses unexpectedly at the end of the day to check if the cash in the register is consistent with the business revenue estimate submitted in the credit application. They also know that the financial statements in loan applications never include the salary of the owner. They estimate the "shadow 
salary" by looking for evidence of the borrowers' household spending, be it a new motorcycle or the size of a home. ${ }^{75}$

On-site loan analysis, combined with the discretionary powers granted to loan officers and local branch offices, significantly speeds up the application process. Given the tight budgets of poor households, access to quick funding in emergencies carries a great premium, usually exploited by moneylenders. Reducing the lag time between loan application and funds disbursement, therefore, is critical for MFIs in attracting customers and competing with other lenders. FINDESA, for example, strives to be "faster than the competition" by cutting this lag to 48 hours and by providing repeat customers with smart cards that deliver loans on demand with no further approval process. ${ }^{76}$

Last but not the least, access to a customer's home and/or business environment serves an important function in terms of delinquency control, especially for individual lenders who cannot exert peer pressure through group meetings or through loan co-guarantors. Having a loan officer drop by and demand action on a late repayment in front of family, neighbors or business associates, or publicly haul out items pledged as collateral, is bound to exert social pressure on borrowers even in dense urban areas where social bonds are be weaker than in closed rural communities.

The principle of going to the customer operates in tension with the need to control costs and shift them onto clients. The tension is minimal in cities and dense rural areas like in Bangladesh, where everyone is close together, but a real barrier in sparse rural areas. In low-density Mongolia, XacBank has built a network of branches that reaches into rural secondary towns; market towns, after all, have been the locus of commerce in rural areas since ancient times. Still, the ratio between overhead costs and clients reached tends to be high in this approach. A modern solution is being tried in Kenya. With support from the U.K. Department for International Development, Kenya's Equity Building Society has deployed mobile banking units-bullet-proof SUVs adorned with solar panels, mobile network-based computer links, and drop-down teller windows. Impressively, Equity reports that it is covering the costs of this advanced equipment through earnings from new business. ${ }^{77}$

\subsection{Standardizing branch structure}

BRANCH STAFFING AT efficient MFIs tends to be tight and uniform, with an organizational structure tailored to the context and the services delivered. In Indonesia, the classic BRI branch has $4^{-}$-IO workers under, at the most, five job titles: unit manager, credit officer (responsible for

loans), teller (occupied primarily with taking deposits), and bookkeeper (likewise), and sometimes a guard. In lower-volume areas, branches operate outposts with just a teller and a bookkeeper, and are open only a few days a week. Grameen branches have tended to be simpler, reflecting the rote nature of solidarity group operations, with a branch manager, sometimes an assistant, and a small corps of field officers. ${ }^{78}$

These simple, standardized units facilitate growth. Typically, MFIs grow fastest through borizontal expansion, opening branches in new territory, rather than vertical expansion, increasing penetration in current territory. Standardizing roles and limiting overall functions allows 
branches to reproduce like cells, growing for a while by expanding local coverage, then splitting in two after territory and clientele reach a certain size. Each new unit is staffed with a combination of veterans taking up their accustomed roles and new hires to whom they pass on their experience. The decision to split requires relatively little involvement from those further up the organizational hierarchy.

Standardization brings the usual disadvantages and advantages of mass production. It imposes some inflexibility, which can impede customer service. But it can make operations efficient (section 1.2.6). And it facilitates learning loops between branches and the center: Any aberrations that signal trouble or innovation are easier for the center to detect against the backdrop of uniformity. And any procedural changes the center issues are meaningful for all branches.

\subsection{Leadership}

FOR AN INDEPENDENT MFI, it almost goes without saying that the drive for success- the vision, the mission, the modus operandi, the commitment to continuous improvement - must come from the top. For microfinance subsidiaries of downscaling banks, whether domestic or international, the need for leadership is worth elaborating on. In fact, two kinds of leadership are needed, argues Liza Valenzuela in a report for the U.S. Agency for International Development. First, the board and CEO of the parent bank must give the microfinance operation a strong mandate, because it breaks from usual bank practices in many ways (such as in the use of pay incentives, below), takes time to break even, and is usually not solely justified by its return-risk ratio. Such a commitment is evident in the few examples of retail microfinance by international banks, such as ABN AMRO, with operations in Brazil, and ANZ Bank, with operations in Fiji. Second, there must be an "operational champion," who runs the microfinance unit, understands all its facets, and has the stature and skill to advocate for the unit within the larger bank, amidst internal competition for capital and autonomy. The leader may also look forward to promotions within the bank conditional on his or her success in microfinance. Valenzuela tells a story of an effective operational champion in a downscaling bank in Latin America:

Asked why his bank's microcredit program succeeded, a board champion said he had selected one of his finest managers to lead the microcredit unit. The manager was an enthusiastic younger man with an excellent understanding of bank products as well as back-office operations. He also came from a rural area and understood rural and lower-income clients. He was an operational champion, someone who knew what it takes to develop a new product line within the bank and could oversee its service delivery. This is a refreshing story, since in many other cases the managers selected have lacked the qualities needed to lead a microcredit program. In fact, many viewed the microcredit job as a demotion. ${ }^{79}$

A 2006 report surveying the experiences of seven downscaling domestic banks concurs, finding that "[m]ost of the successful banks in the analysis had at least one strongly committed manager." 80 


\subsection{Monitoring and incentives}

THE MANAGEMENT DISCUSSION so far has looked at how to find, cultivate, and inspire good workers. But to achieve excellence, managers must also monitor and guide workers after launching them into the field. Collecting data about operations helps them do this. Any signs of repayment troubles must be detected and pounced upon quickly. And since workers are involved in the collection, they absorb messages about what constitutes good performance. Most successful MFIs go beyond collecting performance data to basing a part of employees' pay on it. The result is a flow of information which all involved have strong incentives to care about.

Since a commercially successful MFI's greatest cost is field staff and its greatest risk nonpayment, the most important field worker performance measures to collect are on productivity and arrears. Productivity can be measured as accounts per officer or outstanding portfolio per officer in currency terms. The first relates more closely to the mission of outreach, while the second correlates more with financial sustainability. A second tier of indicators has to do with growth, a high priority after financial sustainability; relevant indicators include gross or net increase in the number of accounts and gross or net increase in portfolio. The goal, in the words of FINDESA head Gabriel Solorzano, is "safe growth." ${ }^{81}$ Whatever indicators are chosen, they should be few and easy to understand, in order to minimize the administrative burden for all concerned and maximize their psychological impact.

A more sophisticated approach to performance measurement is to treat each retail unit as an accounting unit as well, requiring it to generate regular profit and loss statements. P\&Ls do not suffice by themselves, since they may mask portfolio quality problems or "mission creep" away from low-balance clients. But in combination with other indicators, they should align the thinking of field workers more closely with the goal of financial sustainability. The pioneer here is BRI, which since the inception of the Unit system in 1984 has required regular income statements and balance sheets from all branches. ${ }^{82}$

For information to be useful, management information systems (MIS) must be in place to transmit it efficiently, reliably, and quickly. In the rich world, good MIS is seen as synonymous with high technology. Computers, certainly, should be the nerve center of an MFI's information system. But just as an MFI's money flows are not purely electronic (field officers spend much of their time transacting in paper cash) neither need their information flows be. Historically, primary transaction records at Grameen Bank have been kept on paper. Recently, it has accelerated the installation of computers at regional ("area") offices, but it remains to be seen how well the new systems will take-how much, that is, this bit of high technology will improve information flow. ${ }^{83}$ "It is important," wrote Rhyne and Rotblatt in 1994 , "to resist the temptation to equate a good information system with computerization." ${ }^{84}$ Since then, the trend does appear to have been toward pushing modern technology out to the branches and leaves of the organizational tree. Solorzano at FINDESA speaks of putting personal digital assistants (PDAs) in the hands of all field workers. ${ }^{85}$ But the point stands: the key is not whether the technology is paper or silicon but that it serves the essential functions of MIS.

However collected, core performance indicators are typically the basis for pay bonuses. By "putting money first," this practice has the potential disadvantage of undermining commitment 
to the organization's social mission. Grameen Bank says it eschews pay incentives for this reason. ${ }^{86}$ Nevertheless, many MFIs targeting even the poorest through group lending use pay incentives. The fast-growing, profitable Compartamos in Mexico uses them for both its individual and village banking field workers. ${ }^{87}$ Bonuses are almost universal among successful individual lenders because they solve what economists call an information problem. In particular, for the sake of efficiency, individual loan officers must be given more discretion to exercise their own judgment in factoring different kinds of (imperfect) information into loan decisions, especially if they work on the streets, where the clients are. It would be costly for managers to attempt to observe and second-guess every choice they make, so managers cannot be sure field workers are making the best choices. It becomes that much more important to guide their behavior through pay based on results.

Effective pay incentives must possess three characteristics, according to Sebastian von Stauffenberg of MicroRate, an MFI rating agency. ${ }^{88}$ They should be significant enough for field workers to care about them. They should be simple, because it is hard for people to respond to formulas they do not understand. And they should be high-frequency, so that performance affects pay relatively soon. In addition, the basis for incentives needs to be carefully aligned with the MFIs ultimate objectives. Rewarding loan officers only for the number of new accounts opened each month, for example, could tilt operations dangerously in the direction of overlending, even fraud. This, Eduardo Bazoberry reports, once happened at PRODEM in Bolivia, which he runs. ${ }^{89}$ Bazoberry was burned enough by the experience to abandon pay incentives. That put him out of step with most successful individual microlenders but illustrates the risks.

Managers at many effective MFIs view incentive formulas as reins to guide operations. Just as when riding a horse, they can tweak the reins to steer the organization. If they perceive that branches are lending too conservatively, with near-perfect repayment records but slow growth, they can gingerly adjust the incentives to favor growth more, then observe how it affects behavior and performance. In an interesting variant, BRI managers adjust the transfer prices (interest rates) on capital flows between branches and the center. During a nationwide liquidity crunch in I99I, for example, they raised the interest rate paid to branches for mobilized savings. That showed up on the branches' income statements, and since employees shared in the branches' profits, they responded by shifting their energies from the lending program, which temporarily stopped growing, to the savings business. After the credit squeeze passed, BRI managers flipped the incentives to restart lending growth..$^{\circ}$ Managers can also use this technique to mask the subsidy element in the capital they secure, setting transfer prices closer to market rates to promote efficiency.

\subsection{Organizational capacity for learning}

IT IS WELL recognized in rich industrial countries that an organization's capacity for change, or "learning," is essential to success, even survival. The context in which organizations operate is constantly changing - competition arrives, technology advances, or, at MFIs, clients outgrow the strictures of the lending ladder-and so organizations must change too. Even if the context were static, it would remain the case that excellence in complex organizations is not so much achieved 
as continually pursued. And treating employees respectfully, as sources of knowledge, boosts morale.

One striking thing about leaders of successful MFIs that we spoke to is the extent to which they had imbibed these rich-world management ideals as they sought to create world-class institutions. Solorzano said FINDESA models itself after successful Japanese corporations, such as the car companies who imported just-in-time delivery and total quality management from the West - and then implemented them better than any had before. FINDESA executives visited Peru to study its well-developed microfinance regulatory system, to Bolivia to understand why some MFIs came through the late-I99os microfinance crisis better than others, to Mexico to learn from Compartamos, to El Salvador to study a more local example, and to Harvard to study management. In the Japanese model, he says, learning has three parts: class-room learning, onthe-job training, and "self-illumination." ${ }^{11}$

Organizational learning takes many forms, differing in subject (who is learning), object (what is being learned about), and source (internal or external). One kind of learning is about how to improve processes, which Japanese manufacturers exemplify. Excellent MFIs obsess over field officers' time use. In the case of individual lenders, as they mature, the size of a typical client file shrinks radically, in the experience of Sebastian von Stauffenberg. ${ }^{92}$ Over time, they learn how to zero in on a few pieces of information that can be used to accurately gauge a potential borrower's creditworthiness. Paralleling this is a reduction in how many people are involved in a loan decision and how long it takes to make.

Another kind of learning is learning from without, imbibing from the great world of experience and ideas in management and microfinance. Vikram Akula founded SKS in India after observing self-help groups and lenders such as Grameen for years - and watching how Coca-Cola made itself ubiquitous in India in 15 years through mass production of a standardized product. ${ }^{93}$

Still another kind of learning, as Solorzano says, is learning from within. As organizations that mass produce services delivered through large field staffs, power in successful MFIs necessarily flows from the top down. A strong hierarchy dictates standards for products and procedures. Yet knowledge must also flow from the bottom up. Field staff and local branch managers possess the most direct knowledge of what works and what doesn't, of how things are changing on the ground. Consulting them also raises their morale and helps them buy in to any policy changes that emanate from the top. And staff that buy into a policy change are more likely to carry it out with efficiency and excellence. Ultimately, a learning organization is not just a collection of people who learn, but a corporate entity capable of changing in response to new information.

Effective MFI managers therefore develop a culture and procedures that let them learn from staff. Managers at all levels spend time in the field. Regular staff meetings at branches are occasions for local managers to discuss problems and innovations, and similar meetings up the hierarchy facilitate knowledge transmission. Grameen Bank takes an unusual approach: branch managers are required to write monthly essays about conditions in their area, recent successes, challenges, and so on. The essays are sent straight to top management, bypassing the intermediate levels in the hierarchy. "Observers have credited this system with ensuring that the policy makers at Grameen have a detailed grasp of the status of their organization." ${ }^{24}$ Certainly, Grameen has demonstrated impressive capacity to learn in the organizational sense in recent 
years. In response to outside criticism, repayment problems, and pressure from clients given added voice by competition - and despite its size - it carried out the thoroughgoing "Grameen II" reforms in a few years. ${ }^{95}$

\section{Enabling environment}

WE BEGIN THIS section as we began the last, with an observation about the uneven distribution of microfinance in the world. This time, we organize the data geographically to highlight that a few countries have a lot but most have little. (SeeTable 3.) As we have said, the pioneers who created successful MFIs in Bangladesh, Indonesia, Bolivia, and elsewhere deserve much credit, as it were, for their vision, creativity, intelligence, and stamina. But equally talented people work in countries with little microfinance activity. Moreover, since the I990s, bilateral and multilateral donors have promoted microfinance in countries with sizable informal sectors. Currently they disburse are \$o.5-1.o billion a year for microfinance. ${ }^{96}$ International networks like Acción, Women's World Banking, and the Grameen Foundation have also been active in forming alliances with local NGOs-either "start-ups" focused on microlending or older, broad focus social development organizations interested in starting credit programs. Furthermore, private capital funds, attracted by the microfinance success stories, have become active in supporting microfinance initiatives, and domestic commercial banks have also explored downscaling. And now international banks are entering the mix. 
Tablo 3. Aetlvo mleroerodit accounts por eaplta, countrles vith at loast $1 \%$, elrea 2000

\begin{tabular}{|c|c|c|c|}
\hline Country & Loan accounts & Population & Loan accounts/ \\
\hline & (thousands) & & $(\%)$ \\
\hline Bangladesh & 17,300 & 130,407 & 13.3 \\
\hline Indonesia & 15,159 & 224,138 & 6.8 \\
\hline Guatemala & 833 & 12,820 & 6.5 \\
\hline Bolivia & 494 & 8,153 & 6.1 \\
\hline Nicaragua & 220 & 4,932 & 4.5 \\
\hline Gambia & 50 & 1,367 & 3.6 \\
\hline Tunisia & 313 & 9,564 & 3.3 \\
\hline Niger & 322 & 10,174 & 3.2 \\
\hline El Salvador & 191 & 6,123 & 3.1 \\
\hline Honduras & 183 & 6,201 & 3.0 \\
\hline Thailand & 1,728 & 62,352 & 2.8 \\
\hline Ecuador & 345 & 12,505 & 2.8 \\
\hline Sri Lanka & 524 & 19,239 & 2.7 \\
\hline Malawi & 260 & 10,874 & 2.4 \\
\hline Senegal & 233 & 9,784 & 2.4 \\
\hline Mongolia & 61 & 2,601 & 2.3 \\
\hline Peru & 588 & 25,980 & 2.3 \\
\hline Nepal & 492 & 24,702 & 2.0 \\
\hline Cambodia & 243 & 12,433 & 2.0 \\
\hline Benin & 122 & 6,428 & 1.9 \\
\hline Togo & 90 & 5,033 & 1.8 \\
\hline Colombia & 699 & 39,686 & 1.8 \\
\hline Uganda & 407 & 23,496 & 1.7 \\
\hline Bosnia and Herzegovina & 59 & 3,836 & 1.5 \\
\hline Paraguay & 69 & 5,586 & 1.2 \\
\hline Dominican Republic & 97 & 8,354 & 1.2 \\
\hline Georgia & 54 & 4,777 & 1.1 \\
\hline Samoa & 2 & 179 & 1.0 \\
\hline Ethiopia & 638 & 62,651 & 1.0 \\
\hline
\end{tabular}

Source: Authors' calculations, based on CGAP.

Given such widespread support, why then the uneven geographic distribution of microfinance? Positive feedback loops are part of the story. It is easier to do microfinance where it has already been done because clients and regulators have learned how to work with it. Demonstration models are in place and investors are attracted to success. But there is more to the story than that. A country's history, as manifest in its economic regime, culture, and government-is a major determinant of commercial success in microfinance.

\subsection{Positive feedback loops: microfinance begets microfinance}

ONE COMMON THREAD in the stories of countries with MFI success is the demonstration model, the first MFI to attain large outreach and financial viability. It is an example of the 
broader phenomenon of positive feedback, of microfinance begetting microfinance. The demonstration model does several things. It creates public awareness of microfinance. Especially if it is an NGO, the organization's civil society credentials can promote public acceptance of financially viable styles of microfinance, in particular the necessity of charging high interest. This function can be especially important in democracies with a tradition of state subsidized programs of poverty alleviation because some MFI practices can be easily politicized. Given the diversity of credit methodologies and organizational structures, and the importance of creating marketresponsive products, others can learn immensely through the experiences and innovations of the first MFI that successfully tests the waters. Also, if the pioneer is a private MFI, whether forprofit or non-profit, the response of the public sector to private microfinance initiatives-helpful or hostile-becomes evident.

NGOs have perhaps the easiest time pioneering microfinance. But some downscaling state banks, such as BRI, are also well-positioned to take the lead, since they can start with financial muscle, large branch networks, public credibility, and a minimum of worries about regulatory barriers. They can also offer deposit services. Downscaling commercial banks have some of these advantages, but the potential for destructive politicization makes it is harder for easilyscapegoated foreign ones to serve as the pioneers.

The demonstration model also shapes the institutional form of microfinance. If the initial success story is an NGO, other NGOs might be set up; if the lead NGO moved on to become a non-bank finance company (NBFC) or bank, then others will again follow. For new entrants have to compete with the kind of services being provided by the existing MFIs. If the demonstration model is a downscaling state bank or a microfinance bank able to mobilize savings, say, a creditonly NGO might be a weak competitor. Potentially more-successful entrants in such a market would be other downscaling banks.

Positive feedback works its way through other channels. The rise of microfinance forces legal and regulatory adaptations, which opens the way for further growth. The idea of microfinance spreads through communities, so that new entrants need not work so hard to explain what they offer. Success in a country attracts public donors and private investors. In this respect, microfinance is like most explosive phenomena, from the spread of mobile phones to the spread of disease to the acceleration of chip speeds. All are driven by positive feedback loops.

\subsection{National context}

ACCEPTING THE IMPORTANCE of positive feedback loops, the uneven international distribution of microfinance still begs a question: why do certain countries enter the virtuous cycle while others never get past small-scale attempts? The hindrances are economic, cultural, and political. We touch upon some chief examples here.

\subsubsection{Wage rates}

High formal sector wages strain the economics of microfinance. Again, operations dominate the cost structure of MFIs, and consist largely of wages for loan officers. If pay rates for these officers are high relative to the incomes of target clients, MFIs may be faced with a choice 
between charging very high rates or lending larger sums, presumably to less-poor people. Thus the national supply-demand balances for jobs at various skill levels shape the cost structures of lending methodologies. They help determine how far down the income ladder the methodologies can teach, and how much they compete with each other.

Both the determinants of these wage rates and their effects on microfinance economics are complex. One factor behind wage rates is the overall economic inequality in a society. In South Asia, societies are relatively equal and this particular aids the economics of lower-skilled group methodologies, for which high school graduates often suffice. In Bangladesh, formal sector jobs that loan officers qualify for are low-level clerical jobs in government. Salaries for these jobs are low compared to per capita income, relative to other parts of the world, and the demand for them far outstrips supply. By matching the public sector pay scale, Bangladeshi MFIs keep costs low, but still assure themselves a steady supply of loan officers. In I991, when the government of Bangladesh increased government salaries by 50 percent, Grameen had to follow suit. ${ }^{97}$ Given the relative scarcity of public sector jobs, it is doubtful that Grameen would have lost any significant number of employees to the public sector if it hadn't matched the public sector salary increaseit would, however, have lost employee loyalty and undermined its institutional culture. In Latin American, where the rich-poor gap is wider, individual lenders find economic viability, at least in the poorer Latin nations, by hiring university graduates from urban centers and making much bigger loans. Meanwhile, relatively high inequality in African countries, manifest as a few rich people, many extremely poor people, and a tiny middle class of educated workers, may help explain why microfinance has struggled on the continent.

\subsubsection{Competition from the non-MFI private sector}

In richer developing countries, notably in Latin America and Eastern Europe, MFIs are not the only game in town when it comes to formal, privately provided credit. One damper on microfinance growth in Brazil, for example, is a robust consumer credit industry. Microfinance is seemingly the quintessential example of selling to the "bottom of the pyramid." But the first case study in C.K. Prahalad's Fortune at the Bottom of the Pyramid is not of an MFI, but of Casas Bahia, a large Brazilian company that sells consumer goods to poor people on credit. Michael Klein, son of founder and Holocaust survivor Samuel Klein, describes the vision behind the company:

When my father arrived in Brazil, he realized the average population was not wealthy. Thousands of people were migrating from the northeast region to work in São Paolo.... This population needed all kinds of basic goods, such as linens, towels, and sheets. My father's vision was to fulfill the needs of the poor population. But how could they pay for it? The answer was simple: financing. ${ }^{98}$

Casa Bahia is today the Wal-Mart of Brazil, and $80 \%$ of its sales occur on installment credit. As a consumer lender, Casas Bahia does use collateral, namely the things sold. As for MFIs that take collateral, repossessing a television or refrigerator is expensive. But the mere threat of the lossamplified by the public embarrassment of a Casas Bahia truck pulling up in front of one's house to exact it-generally suffices to assure repayment. Casas Bahia's installment credit also 
comports better with Brazilian ideas about finance. In Portuguese, empréstimos, or loans, are what MFIs and other cash lenders provide; the word carries negative connotations because borrowers ultimately pay more than the face value of the money they receive. In contrast, crédito, or credit, emphasizes the idea of just committing to pay for something-later. In a detailed study of financial services in Brazil, Bonnie Brusky and João Paulo Fortuna write, "While it is widely recognized and understood that buying on payment plans is in the end more costly than taking a loan, when the choice is available it is rarely made in favor of a loan."99 Given that microcredit often finances consumption, the presence of the likes of Casa Bahia does narrow the scope for standard microfinance.

\subsubsection{Economic and political competition from subsidized government credit}

One distinguishing characteristic of microfinance has been the way it involves people from rich countries, who advise and finance it. So much does microfinance fill the field of vision of those from rich countries that it can come as a shock to learn that it still provides only a minority of financial services to the poor in developing countries, largely because of large government credit programs in China, India, Vietnam, and other Asian nations. (See Table 4.)

These government programs tend to be subsidized, and competition from them poses a real challenge for MFIs. It can crowd out MFIs - though how much is hard to judge since historically much of it has ended up in the hands of people outside the target population. More importantly, the low interest rates and poor repayment that usually characterize directed credit programs create a culture of easy "credit" that can make it hard for MFIs to control their delinquency levels and politically defend their interest rates. Those who do not gain access to governmentsubsidized credit end up resenting having to pay the higher MFI interest rates. Such resentment is a ready base for politicization of high MFI interest rates.

While the failure of directed credit programs highlights the strengths of the market-oriented microfinance model, in many countries the failure is perceived not as an intrinsic feature of subsidized credit but, rather, as a result of the mismanagement of the government at the time, thus leaving the door open for new directed credit projects with improved delivery systems to be initiated by the latest government-which it will do when it is seeking reelection. In such situations, the public sector continues to be viewed as a better solution than the market for pulling people out of poverty.

A history of directed credit also creates vested interests in the shape of public sector bank managers and employees and the politicians that typically run the local branch of the state bank as if it were part of their general municipal operations. These vested interests can influence government policy into creating a non-supportive MFI environment. The history of India's directed credit program goes back to 1954, when a central bank report recommended expanding the rural cooperative system to provide financial access to what is now called the informal sector. ${ }^{100}$ Commercial banks were nationalized in 1969 and rural regional banks were set up in 1976 to further extend the rural reach of financial institutions. India today has a vast network of rural financial institutions: over 32,000 rural branches of commercial banks and regional rural banks, some I4, OOO cooperative bank branches and 98,000 primary agricultural credit societies, and a vast post-office network with 154,000 outlets providing deposit and money transfer 
services. ${ }^{\text {Ior }}$ Government support for the SHG bank linkage program, discussed in section I.I.I, continues this history.

Unlike the SHG bank linkage program, however, the Grameen replicators in India directly challenge the state banking infrastructure because of their independence and greater scalability. If MFIs achieve broader rural outreach and gain public support, they will undermine the raison d'être of the rural directed credit system. In March 2006, addressing a committee of bankers, the Chief Minister of the Indian state of Andhra Pradesh accused MFIs of charging "moneylender" interest rates and "unethical recovery measures." ${ }^{102}$ Two months later, the same Chief Minister launched a state credit plan to provide funding to SHGs and told reporters that the government was considering regulating MFI interest rates. ${ }^{103}$ In India, the image of a ruthless, cunning, rural moneylender charging usurious rates and pushing the poor to acts of desperation, even suicide, has long persisted in the public imagination and has made it easier for politicians to harness this sentiment to their own goals. ${ }^{\mathrm{I} 4}$

Table 4. Number of small-balance loan accounts by region and institution type, circa 2000

\begin{tabular}{lrrrrr} 
& \multicolumn{2}{c}{ Co-ops and } & \multicolumn{3}{c}{ State/ agricultural/ } \\
Region & \multicolumn{1}{c}{ MFls } & \multicolumn{1}{c}{ credit } & Rural banks development banks & \multicolumn{1}{c}{ Total } \\
\hline Sub-Saharan Africa & 3,956 & 857 & 33 & 348 & 5,193 \\
East Asia and Pacific & 18,292 & 1,069 & 3,147 & 65,624 & 88,133 \\
$\quad$ China & 153 & 18 & & 46,570 & 46,741 \\
Eastern Europe and Central Asia & 430 & 90 & & 28 & 548 \\
Latin America and Caribbean & 4,464 & 655 & 162 & 51 & 5,332 \\
Middle East and North Africa & 909 & 11 & & 5,912 & 6,832 \\
South Asia & 22,366 & 355 & 1,467 & 22,030 & 46,217 \\
$\quad$ India & 3,961 & 51 & & 19,748 & 23,760 \\
\hline Total & 50,415 & 3,037 & 4,809 & 93,994 & 152,255 \\
Share of grand total (\%) & 33 & 2 & 3 & 62 & 100 \\
\hline
\end{tabular}

Source: Consultative Group to Assist the Poor (CGAP), “Financial Institutions with a 'Double Bottom Line': Implications for the Future of Microfinance," Occasional Paper 8, July 2004.

\subsubsection{Macroeconomic stability}

Economic crises can destroy jobs and throw people into the informal sector where they must survive by their wits. In this unhappy way, economic instability expands the market for microfinance. ${ }^{\text {I05 }}$ But MFIs, like most businesses, can hardly thrive in an uncertain climate. Most of all, they need a stable currency. Bolivia's microcredit demonstration model, the NGO PRODEM, was founded in 1986, barely a year after inflation hit a record high of $24,000 \%$ and a new government instituted drastic economic liberalization measures to stabilize the economy, including deregulation of interest rates. Inflation fell to $14 \%$ by 1987 . During the 1990 's, the decade that Bolivian microfinance achieved its remarkable success, economic growth recovered and inflation remained well below the 1987 level. By 1998 , Bolivian microfinance providers served $4 \mathrm{I} 6,000$ clients, accounting for over half of all clients served by the Bolivian financial system. ${ }^{\mathrm{I} 6}$ 
Fortunately inflation is in abeyance worldwide at the moment. In the I980s a typical 30 countries recorded inflation rates above $20 \%$ in any given year. In 2004 , just four did. $^{107}$

\subsubsection{Regulatory environment}

Subsidized credit is not the only public policy that sets the environment for microfinance. Another factor is the tenor of banking regulations and supervision, which can easily quash microfinance if it imposes norms from conventional banking. To quote Damian von Stauffenberg, founder of MicroRate:

A relatively well-developed financial system and above all, reasonably functioning banking laws and institutions that enforce them form a combination that is usually lethal to the emergence of microfinance. Banking supervisors have firm ideas about who should be engaged in financial intermediation and they will nip anything that doesn't conform to those ideas in the bud. It takes a determined political decision - as occurred under Fujimori in Peru and under Gonzalez de Lozada in Bolivia - to change banking laws and to knock the banking supervisors into a cooperative mood. Unfortunately most governments that jump onto the microfinance bandwagon don't realize that the most important thing they can do is boring, largely invisible technical and supervisory work. They want publicity. So they go for lending rate controls and large injections of subsidized funds. Both are poison for microfinance. ${ }^{108}$

A particular threat is a politicization of microfinance that leads to interest rate caps. The tendency is latent in almost all societies and can suddenly come to the fore even in countries where microfinance seems well on its way to success. In Nicaragua, the fifth country on the list in Table 3, the parliament introduced interest rate ceilings in 200I. ${ }^{\mathrm{I09}} \mathrm{Few}$ in the general public understand the business necessity of MFIs charging cost-covering interest rates that happen to be considerably higher than formal market rates. It does seem unfair that the poor have to pay a $40 \%$ interest rate when the rich pay $10 \%$. (And scrutiny of MFI rates and practices, such as in Andhra Pradesh, is not entirely unhealthy.) Making the justification harder is the relative paucity, to date, of conclusive studies vouching for the positive economic and social impact of microfinance (see the Conclusion). Absent such clear evidence supporting the poverty alleviation properties of microfinance, both the necessity and the difficulty of gaining popular support will remain a challenge for MFIs and a tool in the arsenal of vested interests opposed to microfinance.

The good news is that microfinance itself is a force for policy change. An important part of the Bolivia success was not only that banking supervisory agency was one of the best in Latin America by the late I990s, but that it actually was responsive to the needs of microfinance when PRODEM spawned the first full-fledge microfinance bank there, BancoSol. For example, it accommodated BancoSol's violation of traditional collateral requirements, understanding that "unsecured" microloans could be safe. ${ }^{\text {IIO }}$ And during the microcredit crisis in 1999-2000, when competition among MFIs and consumer lenders led to over-lending and a delinquency epidemic, the agency extended its credit bureau to lower-income people. ${ }^{\text {III }}$ These innovations, prodded by the rise of the microfinance pioneers, allowed further growth; again microfinance begat microfinance. 
The broader regulatory milieu also affects microfinance. The government of Turkey, for example, evinces a generally hostile attitude toward small enterprises, including MFIs, favoring large-scale projects in its development strategy. ${ }^{\mathrm{II2}}$ In 2002, KEDV, a Turkish NGO, set up a forprofit company, Maya Enterprise for Microfinance, to start a lending program. Maya received permission to operate after a lengthy application process, yet it is still in legal limbo. While not a bank, Maya is subject to banking tax laws. ${ }^{\mathrm{II} 3}$ A draft law submitted in 2003 and still under consideration three years later proposes regulations for licensing microfinance banks and allows NGOs to lend but does not permit them to own equity in microfinance banks. Worse, it seems that what not expressly permitted there is de facto prohibited, where in other countries the default tends to go the other way. This seriously constrains NGO MFIs, reducing incentives for donors to fund local NGOs interested in microlending. To date, Maya is the only MFI in Turkey, a country of 69 million people, with a stated goal of pursuing financial viability. At the end of 2005 it had I,30I active borrowers. ${ }^{\text {II }}$

\section{Conclusion}

MICROFINANCE LEADERS HAVE developed a suite of techniques in product design and management that solve the business problems of controlling costs, building volume, keeping repayment high, and preventing fraud, all in countries with weak infrastructure and human capital. Most of these techniques were invented, others stumbled upon. Through a process of selection - and in environments friendly to microfinance- the strategies came to the fore for what were predominantly business reasons - the MFIs that followed them became "success stories" in a commercial sense, growing large. For example, the ubiquity of credit, as opposed to savings, seems to have arisen for practical reasons, yet some now call it a human right.

Our focus has been on commercial success. But hardly a dollar goes into microfinance that is not motivated in part by the desire to help the poor. True success is contributing to development. Commercial success is a distinct notion, but the findings of this report about commercial success have implications for thinking about the success of microfinance in the broader sense.

To understand why, one needs to appreciate that how much microfinance helps people is a complex and unsettled matter. It is natural to view the growing clientele and high repayments of MFIs as signs that microfinance works - that fears of debt traps are overblown. People are voluntary partaking of it, and must be doing something right if they are able to repay. Even if they are not investing the loan monies in enterprises with returns that cover the interest, they may be using the funds to smooth consumption, a clinical term that can mean not going to bed hungry so much. Moreover, growing availability of high-quality financial services, like health and education services, is clearly part of economic development. There is much to be said for this line of argument, for trusting the wisdom of the clients. And to the extent that enriching the financial fabric of a country is development, commercial success is almost automatically true development. Certainly, institutions such as BancoSol, Grameen, and BRI are remarkable for their scale and dynamism. 
Yet similar things might be said for moneylenders-people have used their services for millennia - or even tobacco companies moving into developing countries. These analogies are explosive and may be inapt. But they demonstrate the logical shortcoming of equating patronage with success-especially for microfinance investors who define success as direct benefits for clients.

This ambiguity argues for more rigorous evaluation of the impact of microfinance. The need for good evaluation of development projects such as microfinance is not news. What seems underappreciated, however, is that rigorous evaluation of how microfinance affects the poor (which differs from evaluation of how poor microfinance clients are) is rather scarce. ${ }^{\mathrm{II}}$ There are several reasons for this. First, rigorous evaluation is more difficult and expensive than tracking loan repayment or even surveying clients to assess how well off they are. Presented with a prospering microcredit client and a struggling non-client, one could explain the difference in many ways. The MFI may have selected villages or slums, or people within them, that seem most promising. Or selection may operate on the client side, with the more prosperous more likely to borrow and the less prosperous more likely to stay away — or drop out after trying it, thus disappearing from the evaluator's radar. ${ }^{\text {II }}$ Careful evaluation distinguishes these stories from the one of interest, that microfinance is contributing to the prosperity of the client. That turns out to require extensive data collection, such as survey of hundreds of client and non-client households; and, ideally, a randomized implementation of the microfinance program studied, in order to rule out the possibility, say, that the MFI is just giving credit to those who would succeed anyway.

Another disincentive to rigorous evaluation is that it is a "public good": its costs are borne by a few institutions even when it benefits the entire microfinance community. If the institutions funding the evaluation are unlikely to reap most of its benefit, they are less likely to fund it. This might seem a strange assertion given that most of the backers of microfinance are in it for the public good; seemingly, aid agencies and foundations should be eager to generate knowledge on what works. This brings us to the third barrier to evaluation: incentives within funding agencies and MFIs. In general, people within these bodies feel they have more to lose from an unfavorable evaluation that they have to gain from a favorable one.

The upshot, from a decade or so of microfinance evaluation, is a handful of high-quality studies. The chapter on impacts in the 2005 textbook, The Economics of Microfinance, by Armendáriz de Aghion and Morduch, essentially finds two good studies, both of group lending, that find positive impact. ${ }^{\mathrm{II}}$ One of the two cited by Armendáriz de Aghion and Morduch, done in Northeast Thailand, found few statistically significant signs of impact of village banking, except among borrowers on the banks' organizing committees. One explanation is that only these connected borrowers obtained loans large enough that they could reasonably be expected to make a difference. ${ }^{\mathrm{II} 8}$ The other study is based on surveys of $\mathrm{I}, 8 \mathrm{OO}$ households in Bangladesh carried out in $1999^{-}{ }^{-92}$ and $1998^{-} 99$, with backing from the World Bank. It finds that microcredit for women increased their incomes by 8 taka for each Ioo lent. ${ }^{119}$ Thus a $\$ 250$ one-year loan would raise a borrower's income by $\$ 12.50 /$ year, or about $\$ 0.03 /$ day. For someone living on $\$ 2 /$ day, that is a $1.5 \%$ increase. This does not live up to the microfinance hype, but it is a modest, positive impact. ${ }^{\mathrm{I} O}$ Since the publication of the Armendáriz de Aghion and Morduch textbook, 
Dean Karlan and Jonathan Zinman have performed the first randomized study of small-scale credit, specifically, of a payday lender in South Africa; they found that extending credit to those just falling short on the credit scoring system raised borrowers' employment rates and income. ${ }^{\text {I2I }}$ On the other hand, the high-profile "AIMS" impact studies funded by the U.S. Agency for International Development either found no impact or did find it only to have the results undone by other researchers correcting methodological problems. ${ }^{\text {I22 }}$

Microcredit, like all credit, must help some people-one hopes, the majority of clients. And like all credit, especially when pushed hard by suppliers, microcredit must hurt some clients too. This complexity is no more a reason to attack microcredit per se than is personal bankruptcy in rich countries a cause for banning credit cards or adjustable-rate mortgages. But in combination with the observation that commercial imperatives can explain so much about microfinance, it is cause for reflection. By Occam's razor - if two hypotheses explain the evidence, the simpler one is more credible - the power of commercial imperatives to explain so many product design choices weakens an alternative explanation for them, namely that they are made primarily to help clients. Of course, a better way to distinguish the two hypotheses is with direct evidence. More good studies are needed, not least of individual lending, and of services other than credit.

For commercial banks, nontraditional entrants into microfinance, there are some important twists to this general caution. First, if the evidence of benefit is weak, there is a risk that public perceptions of microcredit will flip; the rhetoric of empowerment might even give way to that of enslavement, as it did in the Jubilee 2000 movement to cancel the debt of poor nations. Once, the donors who made those loans were the "good guys" in public perception. Today, there are signs of such a challenge to microcredit in Andhra Pradesh, Bolivia, and elsewhere. The new Bolivian president, for one, called for sweeping debt forgiveness. ${ }^{\mathrm{I} 3}$

Second, it is not necessarily optimal for banks to copy methodologies developed by non-banks. In particular, to the extent that the traditional emphasis on credit is an adaptive response to the difficulty NGOs face in taking deposits, rather than a demonstratively superior way to relieve the capital constraints of the poor, banks should not continue the tradition unquestioningly. They should seriously consider a greater emphasis on savings. The government-controlled BRI Unit system, recall, had 32.3 million deposit accounts to 3 million loan accounts at the end of 2005 . Banks have a competitive advantage in savings. And unlike with credit, there seems little reason to worry that savings harms some clients.

We should not lose sight of the fact that commercially successful microfinance institutions are remarkable organizations, employing hundreds or thousands of people at tasks once thought impossible. They operate in difficult circumstances and are relatively accountable to their clients. They are what William Easterly calls "searchers," incrementally developing responses to the problems of poverty, their efforts channeled by some accountability to those whom they seek to help. ${ }^{\text {I24 }}$ They enrich the institutional fabric of their nations. So even if microcredit does not live up to the hype, if we judge it against realistic expectations, it may be doing quite well. 


\section{Notes}

${ }^{\text {I }}$ Wikipedia, "Microcredit," viewed June 15, 2006, available at

http://en.wikipedia.org/wiki/Microcredit\#History.

${ }^{2}$ Grameen Bank website. See http://www.grameen-info.org/bank/index.html and http://www.grameeninfo.org/bank/nineyearGB.htm.

${ }^{3}$ Consultative Group to Assist the Poor (CGAP), "Financial Institutions with a 'Double Bottom

Line': Implications for the Future of Microfinance," Occasional Paper 8, July 2004

${ }^{4}$ Elisabeth Rhyne, Mainstreaming Microfinance: How Lending to the Poor Began, Grew, and Came of Age in

Bolivia (Bloomfield, CT: Kumarian Press, 200I), p. Ioo.

${ }^{5}$ Pankaj Jain and Mick Moore, "What Makes Microcredit Programmes Effective? Fashionable Fallacies and Workable Realities," Working Paper 177, Institute of Development Studies, Sussex, England, 2003, p. 29.

${ }^{6}$ Westley, Glenn D., 2004, "A tale of four village banking programs: Best practices in Latin America," Inter-American Development Bank, Washington, D.C., p. 29

${ }^{7}$ Ibid., p. 3 I

${ }^{8}$ See, for example, Joseph Stiglitz, "Peer Monitoring and Credit Markets," World Bank Economic Review 4, no. 3 (September 1990), pp. 35 $\mathrm{I}^{-66}$, and Maitreesh Ghatak, "Group Lending, Local Information, and Peer Selection," Fournal of Development Economics 60 (1999), pp. 27-50.

${ }^{9}$ Jain and Moore, op. cit note 5, p. I7

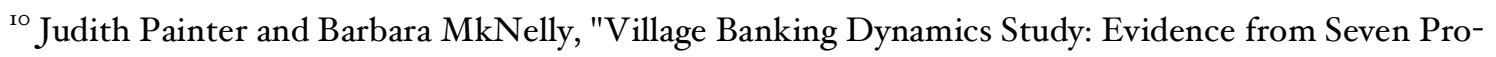
grams," Small Enterprise Education and Promotion (SEEP) Network Research Paper, Washington D.C., 1999; Westley, op. cit noe 6, p. 22: "Pro Mujer, in both its Bolivia and Mexico programs, does not end its village bank meetings until all loan delinquencies are cleared up. Village bank members are expected to extend a loan to any member with a payment shortfall. Many program dropouts complain of these long meetings and of coming to hate meetings instead of enjoying them."

${ }^{\text {II }}$ Stuart Rutherford, Grameen II: The First Five Years, 200I-2005 (Dhaka: MicroSave, 2006).

${ }^{12}$ Cheryl Frankiewicz and Marc de Sousa-Shields, "XAC Bank: From the Liability Side of the Balance Sheet," MicroBanking Bulletin, August 2005.

${ }^{13}$ E. M. O. Masilungan, "Hometown Corporation (B): Expansion Plan," Asian Institute of Management, Makati City, the Philippines, case number AIM-5-05-0002-CS, p. 7 .

${ }^{14}$ Xavier Giné and Dean Karlan, "Group versus Individual Liability: A Field Experiment in the Philippines," draft, April 9, 2006.

${ }^{15}$ Priya Basu and Pradeep Srivastava, "Scaling-up Microfinance for India's Rural Poor," Policy Research Working Paper 3646, World Bank, Washington, DC, 2005.

${ }^{16}$ National Bank for Agriculture and Rural Development web site, http://www.nabard.org/roles/microfinance/files/publications/stmto5_02.pdf.

${ }^{17}$ Average of 17 from Malcolm Harper, "Grameen Bank Groups and Self-help Groups: What are the Differences?" 2002, p. 5, available at http://www.alternative-finance.org.uk/rtf/grameenbankgroups.rtf.

${ }^{\mathrm{I} 8}$ Bindu Ananth, "Financing Micro Finance: The ICICI Bank Partnership Model," Small Enterprise Development I6 (No. I, March 2005), pp. 57-65. 
${ }^{19}$ Gabriel Solorzano, President, FINDESA, Nicaragua, interview with authors, April 27, 2006.

${ }^{20}$ Claus-Peter Zeitinger, Chairman, ProCredit Holding, presentation at Pangea Café, International Finance Corporation, Washington, DC, June 15, 2006.

${ }^{21}$ Klaus Maurer, "Bank Rakyat Indonesia: Twenty Years of Large-Scale Microfinance," in CGAP and the World Bank, Scaling Up Poverty Reduction: Case Studies in Microfinance (Washington, DC: 2004), p. 96.

${ }^{22}$ Solorzano, op. cit. note 19.

${ }^{23}$ Robert Cull, Asli Demirguc-Kunt, and Jonathan Morduch, "Financial Performance and Outreach: A Global Analysis of Leading Microbanks," Policy Research Working Paper 3827, World Bank, Washington, DC, February 2006.

${ }^{24}$ Gary Woller, President, Woller \& Associates, interview with David Roodman, May II, 2006.

${ }^{25}$ Or one can imagine that in the early I980s, a second John Hatch labored with equal enthusiasm to bring financial services to rural Bolivia's poorest, but opted for individual lending; the imaginary experiment failed and was lost to history.

${ }^{26}$ On "human right," see Muhammad Yunus, "What is Microcredit?" January 2003, available at http://www.grameen-info.org/mcredit.

${ }^{27}$ Stuart Rutherford, "The Poor and their Money: An Essay about Financial Services for Poor People," Institute for Development Policy and Management, University of Manchester, January 1999.

${ }^{28}$ Insurance is another potentially powerful service to help household manage risk. In section I.2.8, we discuss credit life insurance. At this point, the art of providing it the poor on a financially sustainable basis lags even that for savings.

${ }^{29}$ See for example, Dean Karlan and Jonathan Zinman, "Expanding Credit Access: Using Randomized Supply Decisions to Estimate the Impacts," draft, July i8, 2006.

${ }^{30}$ Jonathan Morduch, "Does Microfinance Really Help the Poor? New Evidence from Flagship Programs in Bangladesh," draft, June 27, 1998.

${ }^{3 \mathrm{I}}$ Ibid.

${ }^{32}$ Malcolm Harper and Robert Vogel, "The Role of Savings as a form of MFI Funding: Debate," MicroBanking Bulletin, August 2005.

${ }^{33}$ Beatriz Armendáriz de Aghion and Jonathan Morduch, The Economics of Microfinance (Cambridge, MA: The MIT Press, 2005), pp. 59-68, 158-6I.

${ }^{34}$ Manohar Aharma and Gertrud Buchenrieder, "Impact of Microfinance on Food Security and Poverty Alleviation: A Review and Synthesis of Empirical Evidence," in The Triangle of Microfinance, edited by Manfred Zeller and Richard L. Meyer (Baltimore, MD: The Johns Hopkins Press, 2002).

${ }^{35}$ Technically, how much a ROSCA appears to the participant as a savings scheme rather than a loan depends on how late in the cycle she gets a pay-out.

${ }^{36}$ Bank Rakyat Indonesia, International Visitors Program web site, http://www.ivpbri.com, viewed October 3I, 2006.

${ }^{37}$ Zeitinger, op. cit. note 20.

${ }^{38}$ Maurer, op. cit. note $2 \mathrm{I}$.

${ }^{39}$ Conversation with Jonathan Morduch, New York University, New York, March 28, 2006.

${ }^{40}$ Dean Karlan and Jonathan Zinman, "Elasticities of Demand for Consumer Credit," October 24, 2005 . 
${ }^{4 \mathrm{I}}$ Data reported by MFIs posted to the Mix Market (www.mixmarket.org).

${ }^{42}$ Data from Grameen Bank web site, http://www.grameen-info.org/bank/hist2005\$.html, viewed June 23, 2006. Policy change from Shahidur R. Khandker, Baqui Khalily, and Zahed Khan, Grameen Bank: Performance and Sustainability, Discussion Paper 306, World Bank, Washington, DC, October 1995, p. xii.

${ }^{43}$ Anne Marie Goetz and Rina Sen Gupta, "Who Takes the Credit? Gender, Power, and Control over Loan Use in Rural Credit Programs in Bangladesh," World Development 24:I (1995), p. 46.

${ }^{44}$ Goetz and Sen Gupta, op. cit. note 43.

${ }^{45}$ Aminur Rahman, "Micro-credit Initiatives for Equitable and Sustainable Development: Who Pays?" World Development 27:I (1999), p. 70.

${ }^{46}$ Ibid., p. 49.

${ }^{47}$ Connie Bruck, "Millions for Millions," New Yorker, October 30, 2006.

${ }^{48}$ Mix Market, op. cit. note $4 \mathrm{I}$.

${ }^{49}$ Jain and Moore, op. cit. note 5, p. 15.

${ }^{50}$ Rajeev Dehejia, Heather Montgomery, and Jonathan Morduch, "Do Interest Rates Matter? Credit Demand in the Dhaka Slums," Discussion Paper No. 37, Asian Development Bank Institute, Tokyo, September 2005 .

${ }^{5 \mathrm{I}}$ Armendáriz de Aghion and Morduch, op. cit. note 33, pp. 37-41.

${ }^{52}$ SafeSave web site, http://www.safesave.org/people-staff.htm.

${ }^{53}$ Eric Bellman, "Invisible Hand: Entrepreneur Gets Big Banks to Back Very Small Loans," Wall Street fournal, May 15, 2006.

${ }^{54}$ Vikram Akula, Chief Executive Officer, SKS Microfinance, Hyderabad, India, interview with authors, April I6, 2006.

${ }^{55}$ Rutherford, op. cit. note II.

${ }^{56}$ Westley, op. cit. note 6, p. 49

${ }^{57}$ Micro-credit Ratings International, Ltd. (M-CRIL), "Micro-Finance Rating—Risk Assessment: Grameen Koota," rating based on November 2004 assessment, available at http://www.grameenkoota.org/ratingreports/GKSecondMcrilratingreport.pdf.

${ }^{58}$ Michael J. McCord, Felipe Botero, and Janet S. McCord, "AIG Uganda: Good and Bad Practices in Microinsurance," CGAP case study No. 9, 2005, p. I2

${ }^{59}$ Ibid., p.36

${ }^{60}$ Data from CGAP, op. cit. note 3 . They include NGOs, commercial banks, non-bank financial institutions, and charitable projects with a microfinance component.

${ }^{6}$ Individuals may hold more than one account with an institution, or with more than one institution, so the numbers of people represented by these figures is somewhat lower.

${ }^{62}$ It is also conceivable that the economics of microfinance are like that of restaurants: clients can be well served by lots of little ones instead of a few big ones. But this seems unlikely: in countries where microfinance is biggest, it is dominated by a handful of large players.

${ }^{63}$ In Channy, General Manager, ACLEDA Bank, Phnom Penh, interview with authors, April I9, 2006.

${ }^{64}$ Elisabeth Rhyne and Linda S. Rotblatt, What Makes Them Tick? Exploring the Anatomy of Major Microenterprise Finance Organizations, Monograph Series No. 9, Acción International, 1994, p. 69. 
${ }^{65}$ Susan Gibson, "Recruiting, Training, and Retaining Excellent Staff," Countdown 2005, Microcredit Summit Campaign, Washingon, DC, January/February 2000, available at www.microcreditsummit.org/newsletter/bestg.htm

${ }^{66}$ Ibid.

${ }^{67}$ Lokesh Kumar Singh, Manager, Sales and Marketing, SKS Microfinance, Hyderabad, India, interview with authors, April 15, 2006.

${ }^{68}$ Damian von Stauffenberg and Sebastian von Stauffenberg, MicroRate, Arlington, VA, interview with David Roodman, April 6, 2006.

${ }^{69}$ Rhyne and Rotblatt, op. cit. note 64, p. 70.

${ }^{70}$ Channy, op. cit. note 63.

${ }^{71}$ Claus-Peter Zeitinger, Chairman, ProCredit Holding, presentation at Pangea, International Finance Corporation, Washington, DC, June 19, 2006.

${ }^{72}$ Ganhuyag Chuluun, Chief Executive Officer, XacBanc, Ulaanbaatar, interview with authors, April I3, 2006.

${ }^{73}$ Solorzano, op. cit. note I9.

${ }^{74}$ Rhyne and Rotblatt, op. cit. note 64, p. 8I.

${ }^{75}$ Solorzano, op. cit. note 19.

${ }^{76}$ Ibid.

${ }^{77}$ Douglas Pearce and Myka Reinsch, Equity Building Society of Kenya Reaches Rural Markets, CGAP Agricultural Microfinance Case Study No. 4, August 2005.

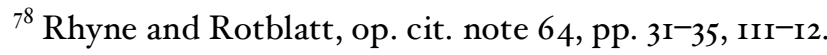

${ }^{79}$ Liza Valenzuela, "Getting the Recipe Right: The Experiences and Challenges of Commercial Bank Downscalers," Development Alternatives, Inc., Bethesda, MD, October 20oI, p. 26.

${ }^{80}$ European Institute for Business Ethics, Global Banks and Microfinance (Amsterdam: ING Bank, 2006), p. 27.

${ }^{8 \mathrm{r}}$ Solorzano, op. cit. note i9.

${ }^{82}$ Maurer, op. cit. note 2I, p. 96.

${ }^{83}$ Rutherford, op. cit. note II, p. 2I.

${ }^{84}$ Rhyne and Rottblat, op. cit. note 64, p. 62.

${ }^{85}$ Solorzano, op. cit. note 19.

${ }^{86}$ Rhyne and Rottblat, op. cit. note 64, p. 58.

${ }^{87}$ Carlos Labarthe, Co-Chief Executive Officer, Compartamos, Mexico City, interview with authors, May 2, 2006.

${ }^{88}$ Sebastian von Stauffenberg, MicroRate, Arlington, VA, interview with David Roodman, April 6, 2006.

${ }^{89}$ Eduardo Bazoberry, "We Aren't Selling Vacuum Cleaners: PRODEM's Experiences with Staff Incentives," MicroBanking Bulletin, April $200 \mathrm{I}$.

${ }^{90}$ Rhyne and Rottblat, op. cit. note 64, p. 55.

${ }^{91}$ Solorzano, op. cit. note 19.

${ }^{92}$ Stauffenberg, op. cit. note 68.

${ }^{93}$ Akula, op. cit. note 54 .

${ }^{94}$ Rhyne and Rottblat, op. cit. note 64 . 
${ }^{95}$ Rutherford, op. cit. note II.

${ }^{96}$ Consultative Group to Assist the Poor, "The Market for Foreign Investment in Microfinance: Opportunities and Challenges," Focus Note 30, August 2005.

${ }^{97}$ Rhyne and Rotblatt, op. cit. note 64, p. 47.

${ }^{98}$ C.K. Prahalad, The Fortune at the Bottom of the Pyramid (Upper Saddle River, NJ: Wharton School Publishing, 2005), p. II8.

${ }^{99}$ Bonnie Brusky and João Paulo Fortuna, "Understanding the Demand for Microfinance in Brazil: A Qualitative Study of Two Cities" (Rio de Janeiro: BNDES, 2002), p. 29.

${ }^{\text {Ioo }}$ Reserve Bank of India, All-India Credit Survey (Bombay: I954).

${ }^{\text {Ior }}$ Basu and Srivastava, op. cit. note 15 .

I02 "AP Plans Strict Action against Errant MFIs," The Hindu Business Line, March I7, 2006, available at http://www.thehindubusinessline.com/2006/03/18/stories/2006031802930900.htm.

${ }_{103}$ "MFIs' Interest Rate to be Regulated," The Hindu, May 23, 2006, available at http://www.thehindu.com/2006/05/23/stories/2006052321420500.htm.

${ }^{\text {I04 }}$ S. Nagesh Kumar, "The makings of a debt trap in Andhra Pradesh," The Hindu, April 20, 2006, available at http://www.hinduonnet.com/2006/04/20/stories/2006042005220900.htm.

${ }^{\text {I05 }}$ Rhyne, op. cit. note 4, p. $4^{2}$.

${ }^{106}$ Sergio Navajas, Jonathan Conning, and Claudio Gonzales-Vega, "Lending Technologies, Competition and Consolidation in the Market for Microfinance in Bolivia," Fournal of International Development I5 (2003): $747^{-} 70$.

${ }^{107}$ Authors' calculations, based on World Bank, World Development Indicators 2006 (Washington, DC: 2006), and on International Monetary Fund, International Financial Statistics (Washington, DC: May 2006).

${ }^{108}$ Damian von Stauffenberg, MicroRate, Arlington, VA, e-mail to David Roodman, April 27, 2006.

${ }^{109}$ Brigit Helms and Xavier Reille, "Interest Rate Ceilings and Microfinance: The Story So Far," CGAP Occasional Paper No. 9, September 2004.

${ }^{\text {IIo }}$ Rhyne, op. cit. note 4, p. I49.

III Ibid, p. I49.

${ }^{\text {II2 }}$ Kiendel Burritt, "Microfinance in Turkey," draft paper for the United Nations Development Programme, published by the United Nations Capital Development Fund, August 2003.

${ }^{\text {II3 }}$ Ibid.

${ }^{\text {II } 4}$ Mix Market, op. cit. note 4I.

${ }^{\text {II5 }}$ For a thorough review of the impediments to rigorous evaluation and a proposal for removing them, see "When Will We Ever Learn? Improving Lives through Impact Evaluation," Report of the Evaluation Gap Working Group, Center for Global Development, Washington, DC, 20006.

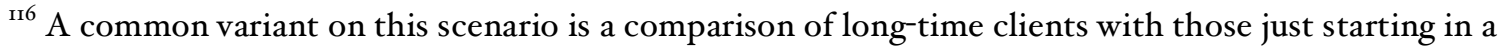
microfinance program, who are taken to proxy for non-clients. For a critique of the method, see Dean Karlan, "Microfinance Impact Assessments: The Perils of Using New Members as a Control Group," Fournal of Microfinance 3(2), Fall 2001, pp. 75-85.

${ }^{117}$ Armendáriz de Aghion and Morduch, op. cit. note 5I.

${ }^{\text {I18 }}$ Brett Coleman, "The Impact of Group Lending in Northeast Thailand," Fournal of Development Economics 60 (1999), pp. 105-42. 
${ }^{\text {I19 }}$ Shahidur R. Khandker, "Microfinance and Poverty: Evidence Using Panel Data from Bangladesh," World Bank Economic Review I9(2), pp. 263-86. 8 taka figure is from the distillation in Armendáriz de Aghion and Morduch, op. cit. note 5I. An earlier paper also belongs in the canon of rigorous studies, but is based only on the $199^{-}{ }^{-}{ }^{2}$ survey and is essentially superseded by the Khandker 2003 paper: 5I Mark Pitt and Shahidur Khandker, "The Impact of Group-Based Credit Programs on Poor Households in Bangladesh: Does the Gender of Participants Matter?" Fournal of Political Economy I06(5) (October 1998 ), pp. $958^{-} 96$

${ }^{120}$ Freedom from Hunger has also commissioned high-quality and encouraging studies of its methodology, which packages credit with basic education in health, nutrition, and business management. But it is impossible to determine from these whether credit per se is helping, beyond its ability to bring groups together for teaching. See Barbara MkNelly and Christopher Dunford, Impact of Credit with Education on Mothers and Their Young Children's Nutrition: Lower Pra Rural Bank Credit with Education Program in Ghana, Freedom from Hunger, Research Paper No. 4 (Davis, CA: Freedom from Hunger, I998), and idem, Impact of Credit with Education on Mothers and Their Young Children's Nutrition: CRECER Credit with Education Program in Bolivia, Freedom from Hunger, Research Paper No. 5 (Davis, CA: Freedom from Hunger, 1999). Future research may let us make the distinction.

${ }^{\text {I2I }}$ Karlan and Zinman, op. cit. note 3I.

${ }^{122}$ Armendáriz de Aghion and Morduch, op. cit. note 51.

${ }^{123}$ Elizabeth Littlefield, President, CGAP, keynote speech at conference on Access to Finance, World Bank, Washington, DC, May 3I, 2006.

${ }^{124}$ William Easterly, The White Man's Burden: Why the West's Efforts to Aid the Rest Have Done So Much Ill and So Little Good (New York: Penguin Press, 2006). 


\section{Appendix. Experts Interviewed}

\begin{tabular}{|c|c|c|}
\hline $\begin{array}{l}\text { Vikram Akula } \\
\text { CEO } \\
\text { SKS Microfinance } \\
\text { India }\end{array}$ & $\begin{array}{l}\text { Carlos Labarthe } \\
\text { Co-CEO } \\
\text { Compartamos } \\
\text { Mexico }\end{array}$ & $\begin{array}{l}\text { Lokesh Kumar Singh } \\
\text { Lead Manager } \\
\text { SKS Microfinance } \\
\text { India }\end{array}$ \\
\hline $\begin{array}{l}\text { Robert Annibale } \\
\text { Global Director, } \\
\text { Microfinance } \\
\text { Citigroup }\end{array}$ & $\begin{array}{l}\text { Levan Lebanidze } \\
\text { Executive Director } \\
\text { Constanta Foundation } \\
\text { Georgia }\end{array}$ & $\begin{array}{l}\text { Gabriel Solorzano } \\
\text { President } \\
\text { FINDESA } \\
\text { Nicaragua }\end{array}$ \\
\hline $\begin{array}{l}\text { Deborah K. Burand } \\
\text { Executive Vice President } \\
\text { Grameen Foundation USA }\end{array}$ & $\begin{array}{l}\text { Jonathan Lewis } \\
\text { CEO } \\
\text { MicroCredit Enterprises }\end{array}$ & $\begin{array}{l}\text { Damian von Stauffenberg } \\
\text { CEO } \\
\text { MicroRate }\end{array}$ \\
\hline $\begin{array}{l}\text { In Channy } \\
\text { General Manager } \\
\text { ACLEDA Bank } \\
\text { Cambodia }\end{array}$ & $\begin{array}{l}\text { Elissa McCarter } \\
\text { Director, Office of } \\
\text { Development Finance } \\
\text { CHF International }\end{array}$ & $\begin{array}{l}\text { Sebastian von Stauffenberg } \\
\text { MicroRate } \\
\text { Blaine Stephens } \\
\text { Senior Analyst }\end{array}$ \\
\hline $\begin{array}{l}\text { Paul Christensen } \\
\text { President } \\
\text { ShoreCap Management }\end{array}$ & $\begin{array}{l}\text { Kate McKee } \\
\text { Director, Microenterprise } \\
\text { Development office } \\
\text { USAID }\end{array}$ & $\begin{array}{l}\text { Microfinance Information } \\
\text { eXchange (MIX) } \\
\text { Brad Swanson }\end{array}$ \\
\hline $\begin{array}{l}\text { Ganhuyag Chuluun } \\
\text { CEO } \\
\text { XacBanc } \\
\text { Mongolia }\end{array}$ & $\begin{array}{l}\text { Ann Miles } \\
\text { Director } \\
\text { Blue Orchard }\end{array}$ & $\begin{array}{l}\text { Partner } \\
\text { Developing World Markets } \\
\text { Gary Woller }\end{array}$ \\
\hline $\begin{array}{l}\text { Gil Crawford } \\
\text { General Manager } \\
\text { MicroVest }\end{array}$ & $\begin{array}{l}\text { Jonathan Morduch } \\
\text { Professor } \\
\text { New York University }\end{array}$ & $\begin{array}{l}\text { Woller \& Associates } \\
\text { Flavio Weizenmann } \\
\text { Senior Vice President }\end{array}$ \\
\hline $\begin{array}{l}\text { Sasha Dichter } \\
\text { Global Manager, Corporate } \\
\text { Citizenship } \\
\text { GE Money }\end{array}$ & $\begin{array}{l}\text { Didem Rastgeldi } \\
\text { Operations Manager } \\
\text { Maya Enterprise for } \\
\text { Microfinance } \\
\text { Turkey }\end{array}$ & $\begin{array}{l}\text { Banco Real } \\
\text { Brazil }\end{array}$ \\
\hline $\begin{array}{l}\text { Martin Holtmann } \\
\text { Lead Microfinance Specialist } \\
\text { CGAP }\end{array}$ & $\begin{array}{l}\text { Beth Rhyne } \\
\text { Senior Vice President } \\
\text { Acción International }\end{array}$ & \\
\hline $\begin{array}{l}\text { Jennifer Isern } \\
\text { Lead Microfinance Specialist } \\
\text { CGAP }\end{array}$ & $\begin{array}{l}\text { David Schwarzbach } \\
\text { VP, Business Development } \\
\text { Net I UEPS Technologies }\end{array}$ & \\
\hline $\begin{array}{l}\text { Gautam Ivatury } \\
\text { Manager, Microfinance } \\
\text { Technology Program } \\
\text { CGAP }\end{array}$ & $\begin{array}{l}\text { Moumita Sensarma } \\
\text { VP, Head of Microfinance \& } \\
\text { Sustainable Development } \\
\text { ABN AMRO } \\
\text { India }\end{array}$ & \\
\hline
\end{tabular}




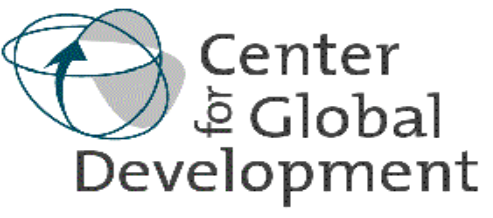

1776 Massachusetts Avenue NW, Third Floor, Washington DC 20036 Tel 202.416.0700 | Fax 202.416.0750 www.cgdev.org 